\title{
FINANCE AND CREDIT IN A MODEL OF MONETARY POLICY
}

\section{Jagjit S. Chadha Young-Kwan Kang ${ }^{1}$}

${ }^{1}$ University of Kent, Canterbury and The Bank of Korea

NIESR Discussion Paper No. 471

Date: 20 October 2016 


\section{About the National Institute of Economic and Social Research}

The National Institute of Economic and Social Research is Britain's longest established independent research institute, founded in 1938. The vision of our founders was to carry out research to improve understanding of the economic and social forces that affect people's lives, and the ways in which policy can bring about change. Seventy-five years later, this remains central to NIESR's ethos. We continue to apply our expertise in both quantitative and qualitative methods and our understanding of economic and social issues to current debates and to influence policy. The Institute is independent of all party political interests.

National Institute of Economic and Social Research

2 Dean Trench St

London SW1P 3HE

T: +44 (0)20 72227665

E: enquiries@niesr.ac.uk

niesr.ac.uk

Registered charity no. 306083

This paper was first published in October 2016

(c) National Institute of Economic and Social Research 2016 


\section{Finance and Credit in a Model of Monetary Policy}

\section{Jagjit S. Chadha and Young-Kwan Kang}

\section{Abstract}

Economies is the extent to which a workhorse advanced economy model can yield important insights for monetary policy-making. We note that the standard sticky-price, monopolistically competitive model does not allow analysis of money and credit dynamics and led to a concentration of research on simple interest rate reaction functions. Time-varying financial frictions tend to act as a tax on intermediation activities and so can vary output in a significant manner. In this paper, we consider the implications of financial frictions for baseline monetary policy using a model calibrated on Indian data and find that a simple interest rate reaction function may not be welfare maximising,

\section{Acknowledgements}

I am grateful for helpful conversations and comments from Philip Arestis, Chetan Ghate, Mike Joyce, Ken Kletzer, Jack Meaning, James Warren and participants at the BIS-OECD Workshop Panel on Policy Interaction: Fiscal Policy, Monetary Policy and Debt Interaction, the Reserve Bank of India. Also I thank Luisa Corrado, Germana Corrado, Sean Holly, Philip Tuner, Alex Waters and Fabrizio Zampolli for permission to draw on joint work. Any remaining errors are our own.

\section{Contact details}

Jagjit S. Chadha (j.chadha@niesr.ac.uk), National Institute of Economic and Social Research, 2 Dean Trench Street, London SW1P 3HE 


\title{
Finance and Credit in a Model of Monetary Policy*
}

\author{
Jagjit S. Chadha ${ }^{\dagger}$ and Young-Kwan Kang ${ }^{\ddagger}$
}

\section{October 2016}

\begin{abstract}
economies is the extent to which a workhorse advanced economy model can yield important insights for monetary policy-making. We note that the standard stickyprice, monopolistically competitive model does not allow analysis of money and credit dynamics and led to a concentration of research on simple interest rate reaction functions. Time-varying financial frictions tend to act as a tax on intermediation activities and so can vary output in a significant manner. In this paper, we consider the implications of financial frictions for baseline monetary policy using a model calibrated on Indian data and find that a simple interest rate reaction function may not be welfare maximising.
\end{abstract}

JEL Classifications: E43, E44, E47, E58

Keywords: DSGE models, Financial Frictions, Monetary and Fiscal Policy.

*I am grateful for helpful conversations and comments from Philip Arestis, Chetan Ghate, Mike Joyce, Ken Kletzer, Jack Meaning, James Warren and participants at the BIS-OECD Workshop Panel on Policy Interaction: Fiscal Policy, Monetary Policy and Debt Interaction, the Reserve Bank of India. Also I thank Luisa Corrado, Germana Corrado, Sean Holly, Philip Tuner, Alex Waters and Fabrizio Zampolli for permission to draw on joint work. Any remaining errors are our own.

${ }^{\dagger}$ NIESR, University of Kent, Canterbury and University of Cambridge. E-mail: J.Chadha@niesr.ac.uk; jsc@kent.ac.uk; jsc38@cam.ac.uk.

${ }^{\ddagger}$ University of Kent, Canterbury and The Bank of Korea. E-mail: yk73@kent.ac.uk; praxisyk@bok.or.kr. 


\section{Introduction}

global financial crisis has promoted an explosion of work by macroeconomists in both advanced and emerging countries developing micro-founded models with financial frictions. Such frictions tend to lead to time-varying endogenous wedges between different sets of market interest rates in which changes in money or credit supply may impact and change both aggregate demand and potential output levels. ${ }^{1}$ In this paper we will show how microfounded models can be extended to encompass financial frictions, without necessarily sacrificing internal coherence, and also consider the implications for monetary policy in India. ${ }^{2}$ Naturally, when we consider India financial frictions pervade economic analysis: (i) external financing constraints may effect the demand for foreign exchange reserves; (ii) the informal sector may be segmented from financial issues; ${ }^{3}$ (iii) consumers and firms may face collateral constraints; (iv) banks and other financial intermediaries may face some form of 'repression' and (v) the government seems likely to face inelastic demand for debt denominated in domestic or, even, foreign currency. ${ }^{4}$ Rather than addressing each of these frictions, we shall concentrate on considering the implications of collateral constraints in a model of loan production by commercial banks and examine the extent to which this friction complicates the choice faced by monetary policy makers.

The long global economic expansion from the early 1990s to late 2008 was a period in which finance became both content and proud, perhaps through benign neglect. ${ }^{5}$ Financial engineering and innovation created new bridges from savers to borrowers within countries and internationally and it seemed to many that credit markets were well-oiled by the financial sector and financial spreads became increasingly compressed. ${ }^{6}$ In parallel, in the workhorse models of this period, the typical rigidities were simply those of sticky prices and monopolistic competition, which generated deviations from the flex-price equilibrium in response

\footnotetext{
${ }^{1}$ See Chadha and Holly, Eds., (2011) for a treatment of a number of partial equilibrium and general equilibrium modelling approaches that try to understand non-conventional monetary policies. Although there is a growing literature, a workhorse model has not yet been developed.

${ }^{2}$ The call for more work on the monetary-financial nexus was made by Hammond, Kanbur and Prasad (2009). This paper forms part of an answer.

${ }^{3}$ See Khan and Thomas (2014) on this important point. Note that if some markets are segmented financially then policy may have work harder to influence or act on those markets on which it has some (limited) influence.

${ }^{4}$ The agenda involves writing down general equilibrium models built from the principles of household optimisation that match key stylised facts of business cycle behaviour. The model can then be solved under various forms of stabilisation policies under which the welfare of the household can be assessed and in which the Lucas critique is respected. Gabriel et al., (2012 and 2016) support the need to include financial frictions in their estimated DSGE models of first a closed and then an open economy.

${ }^{5}$ In 1925 prior to making the decision to return to an overvalued gold standard, Churchill had called for industry to be more content and finance less proud. By 2007, finance, it seemed to many, had it all.

${ }^{6}$ With the development of many new credit instruments and the increasing levels of leverage of financial institutions, it seemed that markets were being completed.
} 
to exogenous shocks. Accordingly, the output gap and the inflation rate became a sufficient pair of statistics to monitor the economy. ${ }^{7}$ In a forward-looking model agents simply had to know enough to understand that the monetary authorities would act on the short-term real rate to close any expected output gap in expectation and thus any deviation from the stated inflation target. Control of this real interest rate by the central bank was all that was required in order to achieve stability. ${ }^{8}$

But the prescriptions of the workhorse micro-founded model did not help us understand the policy initiatives developed in the crisis. Monetary policy became constrained at the zero lower bound and this led to the rediscovery of importance of open market operations, or balance sheet policies, as a way of influencing interest rates beyond the normal policy horizon. It was well known that fiscal policy operated to help aggregate demand in a recession but here it was called up also to recapitalise banks. This extra function as a fiscal 'backstop' meant that any concern about borrowing limits would not only frustrate countercyclical policy because escalating market determined interest rates would bear down on activity but potentially leave the financial sector highly vulnerable to further shocks. Furthermore the fragility of the role of commercial banks as maturity transformers was revealed and the systemic lack liquidity in the event of risk aversion exposed. Balance sheet operations expanded the size and composition of the central bank balance sheet and reduced the duration of financial markets' bond holdings and increase liquidity. These operations involve the issuance of short term debt-fiscal instruments (interest rate bearing reserves or T-Bills). So as well as helping to reduce long term rates by signalling lower rates or by offsetting risk premia, these monetary-fiscal operations hedged liquidity risk. In some sense, advanced country central banks stumbled towards these solutions and need to develop models to help us understand the extent to which they should remain part of the policymaker toolkit in advanced or emerging economies.

For an emerging economy, these operations by advanced economies had a two-fold implication of first making it less clear that these economies should necessarily continue to liberalise financial markets and secondly imparted a wave of capital inflows seeking higher yields than were typically available in the advanced economies. Although we retain a closed economy structure we can use the model to understand the implications of the kinds of driving forces that increase the availability of money and credit with our model of loans production. ${ }^{9}$ India started a process of financial liberalisation in the early 1990s in parallel

\footnotetext{
${ }^{7}$ Ironically at the same time, many of the price rigidities were being nicely ironed out by an explosion in production from China.

${ }^{8}$ In Chadha et al. (2013b), we show how money and financial factors were excluded by design from having any amplification impact in the standard model.

${ }^{9}$ See Mohanty and Rishabh (2016) in this volume for an analysis of open economy issues facing emerging economies. We maintain that the key issue is always the scale and cost of the supply of loanable funds whether from local sources or from abroad.
} 
with the long economic expansion in the advanced economies. And we are interested in understanding how an emerging economy should set policy in light of the relaxation of financial repression, which implies a move to market determined interest rates, and as a consequence of lessons learnt from the financial exuberance in advanced economies.

Using a micro-founded model calibrated to the Indian economy, we examine the efficacy of a standard active interest rate reaction function of the type adopted by advanced economies in the decade leading up to the financial crisis. In our model the commercial banking sector provides loans on the basis of posted collateral, the value of which is heavily pro-cyclical, which leads to countercyclical lending spreads that tend to amplify the economic cycle. We find that the economy exhibits less volatility if commercial banks can vary (or choose) their reserve-deposit ratio over the business cycle. By paying attention to the provision of central bank money (or reserves), the policy maker can militate against the commercial banks seeking to offset the costs a fixed reserve deposit ratio by varying market interest rates more than they would otherwise. Time variation in the reserve-deposit ratio acts as a time varying subsidy (or tax) on lending. An augmented policy rule that feeds back from various market spreads, or so-called financial conditions, may offer an alternate path.

In the next section we present a brief overview of the simple rules debate and how financial premia impact on the economy. Section 3 then discusses the external finance premia and its introduction into macro models. In section 4 we outline a model of financial frictions and consider the monetary policy problem. Section 5 offers the main calibrated and simulated results. The final section concludes with some thoughts on financial frictions.

\section{Standard Sticky Price Monetary Policy}

Let us remind ourselves about the policy prescriptions that emerged from the monopolistically competitive sticky price version of a DSGE model. Then we shall turn to the basic insight offered by the existence of a financial wedge and provide some intuition on the likely consequences for policymaking. This framework seems close to that which the RBI seems to want to adopt a framework for thinking about monetary policy in the presence of financial frictions. ${ }^{10}$

\subsection{Simple Monetary Policy}

In the simple linearised New Keynesian model (see Figure 1). The policy reaction function simply has to react by more than any given change in inflation so that the (economy-wide) real interest rate acts to bear down on any output gap and drive inflation back to its target.

\footnotetext{
${ }^{10}$ See IMF Article IV consultations (e.g. 2015) on the Indian monetary policy problem.
} 
This linear model is subject to a number of well known control problems: (i) changes in the natural rate (the intercept), which cannot be easily measured, will lead to monetary impulses from nominal rates that imply an incorrect real rate of interest; (ii) measuring the output gap and then forecasting the change in the inflation that is implied is very difficult in real-time; (iii) with no constellation asset prices in the model, we are left hoping that use of a single policy rate leads to clearing in credit markets that does not leave the economy in a fragile state and (iv) finally if rates were to fall to zero and deflationary pressures continued to escalate, real rates would rise and the economy would be in serious danger of not being able to be stabilised around the normal target.

The need for microfoundations for financial frictions is thus motivated by each of these objections. The natural rate can be interpreted as that reflecting monetary and financial conditions elsewhere, so that, for example, if the financial sector is expanding at a fast rate, the natural rate rises. The operation of the financial sector may impact on both measured potential supply and current demand and thus make any kind of output gap calculation almost impossible. Money market clearing in a host of short term and long term financial markets will determine the set of interest rates that are relevant for the consumption and investment decisions and these may not be strictly proportional to the short run policy rate at all times - in the language of finance, they may be disconnected. Finally, if the policy rate hits the lower zero bound, we may need to think about operating on other asset and bond prices in order to gain some traction on the monetary transmission mechanism. ${ }^{11}$

\section{$2.2 \quad$ Financial Wedges}

There is no workhorse model for understanding all types of financial frictions. But Hall (2009) provides a useful taxonomy. He reminds us that an increase in any financial friction will tend to increase the interest rate wedge between those who provide capital and the cost of capital paid by firms. Let us consider a static standard Cobb-Douglas production sector with driving forces that may include government purchases and efficiency. In such a model another driving force might be a tax on the difference between payments to the capital factor and the price of capital. An increase in such a wedge will tend to depress output and employment, and the converse will hold true with reductions in the wedge tending to create a boom. The story is akin to that arising from the Diamond-Mirrlees analysis of the inefficiency of taxing an intermediate product, with capital playing the role of an intermediate product.

The legs of the argument are that an increase in financial frictions acts to increase the price of capital and so reduce its demand. Because of the economy-wide resource constraint this will increase both the output-capital ratio and the consumption-capital ratio accordingly.

\footnotetext{
${ }^{11}$ In our model developed in detail later we can assess (i) and (iii) but elsewhere we have studied (ii) and (iv).
} 
Through the Cobb-Douglas production function the labour-capital ratio rises along with output-capital and induces a fall in real wages. The household balances its demand for goods consumption against the supply of hours worked and this allows us to solve for the optimal level of capital, which is lower than prior to the financial frictions shock. The lower level of capital induces a fall in output. The argument goes through in the opposite direction with a fall in the size of financial frictions increasing output. Indeed under this kind of analysis financial frictions are embedded in the supply side of the economy and may be particularly hard to understand in NK models, which concentrates on demand and cost-push shocks in the production of goods. Though qualitatively, changes in the financial wedge seem to have a similar effect to a payroll tax, which places a wedge between wages received by workers and paid by employees. Hall (2009) finds that a 6 percentage point increase in the financial spread can induce a recession that size of that experienced by many advanced economies after the start of the financial crisis.

\subsection{Flex-Price Model}

Chari, Kehoe and McGratten (2007) argue forcefully that financial frictions do not only inhabit the wedge between the rental price of capital and return to capital, arguing that frictions in the financing of inputs may provide an important explanation for changes in the observed wedge between aggregate inputs and outputs, so-called efficiency. They suggested a now widely-applied technique for decomposing aggregate fluctuations into four time-varying wedges: efficiency (including input financing), investment (the mark-up on the price of capital), labour (the mark-up on labour inputs) and government consumption. The point of departure is consumer maximisation of utility given the choice of consumption and labour into which wedges are placed:

$$
\max _{c_{t} l_{t}} E_{0} \sum_{t=0}^{\infty} \beta^{t} U\left(c_{t}, l_{t}\right) N_{t},
$$

subject to a flow budget constraint,

$$
c_{t}+\left(1+\tau_{x t}\right) x_{t}=\left(1-\tau_{l t}\right) w_{t} l_{t}+r_{t} k_{t}+T_{t},
$$

where $c_{t}$ is consumption at time $t, x_{t}$ is investment, $\tau_{x t}$ and $\tau_{l t}$ are the time varying tax rates (or wedges) on investment and labour, $w_{t}$ is the wage rate, $r_{t}$ is the real interest rate $T_{t}$ are lump sum taxes, $N_{t}$ is population, $\beta$ is the discount factor, and $k_{t}$ is the capital stock. Firms maximise profits. 


$$
\max _{k_{t}, l_{t}} A_{t} F\left(K_{t},(1+\gamma)^{t} l_{t}\right)-w_{t} l_{t}-r_{t} k_{t}
$$

where $A_{t}$ represents the efficiency wedge (between aggregate inputs and outputs) and like standard real business cycle models this parameter is exogenously determined from the model the parameter $(1+\gamma)$ is the rate of labour augmenting technical progress. The law of motion of capital is given by;

$$
(1+\lambda) k_{t+1}=(1-\delta) k_{t}+x_{t}
$$

where $(1+\lambda)$ is the growth rate of the population which is a constant and $\delta$ is the depreciation rate. The equilibrium conditions of the economy are as follows, with first the resource constraint:

$$
\begin{gathered}
c_{t}+x_{t}+g_{t}=y_{t} \\
y_{t}=A_{t} F\left(K_{t},(1+\gamma)^{t} l_{t}\right) \\
-\frac{U_{l t}}{U_{c t}}=\left(1-\tau_{l t}\right) A_{t}(1+\gamma)^{t} F_{l t} \\
U_{c t}\left(1+\tau_{x t}\right)=\beta E_{t} U_{c t+1}\left[A_{t+1} F_{k t+1}+(1-\delta)\left(1+\tau_{x t+1}\right)\right] .
\end{gathered}
$$

The wedges thus can be described as the following, the parameter $A_{t}$ is the efficiency wedge at time $t$, and captures any distortion that may cause the representative firm to allocate resources more efficiently. The labour wedge is described by $\left(1-\tau_{l t}\right)$ and captures any effects which separate the marginal product of labour (rhs of 7 ) from the marginal rate of substitution between consumption and labour (lhs of 7). The investment wedge is given by $\frac{1}{\left(1+\tau_{x t}\right)}$ which captures anything which separates the intertemporal rate of substitution in consumption from the asset pricing kernel. It is important to note that the wedges do not pick out a single type of distortion within the wedge rather they capture all possible distortions that may affect labour, investment and efficiency, with government expenditure operating as something of a residual.

In most studies of business cycle accounting, it is found that the efficiency and labour wedges account for most of measured business cycle fluctuations, see Kehoe and Prescott (2002). Indeed in their examination of the BRIC economics, Chakraborty and Otsu (2013) largely concur but do find a significant role for the investment wedge in India during the 2000s. It is therefore not clear whether under some parameterisations of these models the 
investment wedge may have a larger role to play than initially thought or whether this framework systematically overestimates the role played by efficiency wedges, echoing the RBC literature of the 1980s. Even if that is the case, it might be that changes input financing might help us understand changes in measured economy-wide efficiency.

\subsection{The Recent Deep Recession}

The kind of analysis outlined in the previous section tends to lead to the conclusion that in response to changes in financial frictions, consumption and investment ought to move in opposite directions as the economy switches from capital to labour. But what we consistently find in many economies is that consumption and investment move together quite markedly, especially in the recent recessions across the advanced economies, which most commentators think were closely related to revelation of large-scale external financial frictions. This means that we need to find micro-foundations for frictions that drive consumption and investment in the same direction over the business cycle. In fact the problem is even worse. Chadha and Warren (2012) took a model in which an external financial premium was driven negatively by asset prices (in the spirit of Bernanke, Gilchrist and Gertler, 1999) and allowed the relative magnitude of asset prices to increase markedly relative to productivity and various demand shocks. Taking data from the model simulated with all these shocks, they examined the evolution of output without each of four possible wedges, or shocks: investment ( $a k a$ financial), labour or efficiency (or productivity) and/or government. And when they accounted for the causes of the business cycle in the data produced by this model, in the fashion of Chari, Kehoe and McGratten, 2007, they found that it was when the efficiency/productivity wedge was removed that the model performed the worst.

In other words the shock driving the external finance premium looks like a productivity or efficiency wedge because it drives consumption and investment in the same direction. It is therefore important in our model that we do employ a set-up where consumption and investment co-move positively. ${ }^{12}$ This finding means that financial frictions may tend look like a supply shock in a macro-model, or in the language of CKM an input financing shock. As far as the early part of the twenty-first century was concerned therefore, the apparent fall in financial frictions would have been observationally equivalent to an increase in productivity and would simply have led to the central bank stoking up more demand to meet its inflation target. The problem was, of course, that the financial frictions were about to return with a vengeance.

\footnotetext{
${ }^{12}$ In the model have two types of frictions in the investment decision. First, loans for investment are subject to a costly production function and secondly we also have some costs in the actual investment function. Both are required to have consumption and investment co-move positively.
} 


\section{The External Finance Premia}

To help illustrate the implications of financial frictions for demand, Figure 2 (from Chadha et al., 2010) traces the impact of the external finance premia on activity, as measured by consumption. In this representation the central bank, in the top right-hand side quadrant, sets the policy rate and supplies central bank money on demand in response to any shifts in money demand. The banking system chooses the quantity of broad money that it wants to create from the MM curve, which can be thought of as an optimising decision. There need not be a fixed multiple of broad but the final choice of the financial system implies a particular multiplier. The demand for broad money falls in the EFP and the supply increases to set a level of demand at $A$, which is consistent with a given level of broad and narrow money, as well as the prevailing policy rate. But any exogenous shifts in the supply of broad money will thus change the external finance premium and the level of output to $A^{\prime}$ or $A^{\prime \prime}$. Thus broad money and the level of activity can be quite distinct from the policy rate or the quantity of central bank money. And, if the lending function, relates to some measure of the financial friction, we might be moving closer to a story in which expenditure components that rely on bank lending may covary over the business cycle and be linked directly to the supply of loans. What we would like to have, in terms of microeconomic foundations, is a consumption (and investment) path that is not only tilted by the policy rate but also affected by the quantity of credit offered.

\subsection{Open market operations and money}

If the policy rate is fixed or bounded at the lower zero bound, policy makers may wish to introduce forms of open market operations to influence market interest rates further along the maturity spectrum. ${ }^{13}$ And so generally speaking, new initiatives such as quantitative easing are really just an extended open market operation involving the unsterilised swap of central bank money for privately held assets. The key difference is that the duration of the swap is both intended to be long-term and of uncertain length. An open market operation, if unsterilised, leads to an increase in the quantity of base or outside money. This money represents claims on the public sector and will not be neutral with respect to any given expenditure plans if there is a real balance effect that induces a fall interest rates. This is because the increase in money changes the price of claims on the public sector. If, however, the private sector fully discounts the present value of taxes that will need to be paid to meet these obligations then these bonds will not represent net wealth and the operation will be neutral. The debate on the efficacy of such operations hinged on the question of whether the supply of outside money changes the wealth position of the private sector (see Gale, 1982).

\footnotetext{
${ }^{13}$ The discussion in this section follows closely that of Breedon et al. 2012.
} 
But the analysis of such operations lays outside the remit the workhorse New Keynesian (NK) Model in which the evolution of monetary aggregates, which are simply a veil by which real planned transactions were effected, provided no additional feedback to the state of the economy. These models, as already explained, are highly tractable and were used to develop simple, precise policy prescriptions, even at the lower zero bound of Bank rate, by influencing expectations of the duration of any given level of Bank rate in order to induce exchange rate depreciations or positive inflation shocks and so close any given sequence of output gaps in expectation. In these models, open market operations were neutral because at the lower zero bound money and bonds become perfect substitutes and any swap of one for the other does not change the wealth position of the private sector. In fact, in these models QE-type policies are simply forms of commitment strategies that provide signals about the long term intentions of the central bank to hit a given inflation target.

The NK argument that monetary policy can only work through the management of expectations is not a universal result as it relies on particular assumptions. In these models, financial markets are complete in which a representative agent can spring into life and financial wealth is allocated over an infinite life. Idiosyncratic risk in these economies can be hedged and asset prices depend on state-contingent payoffs. In this case, the price of financial assets are not influenced by changes in their net supply, as demand is perfectly elastic. It seems quite possible though that demand curves for assets, particularly which are issued in large quantities, may become downward sloping, in which case changes in net supply can affect their relative prices. ${ }^{14}$ This possibility then means that the relative supply of money or credit can influence market interest rates and so impact directly on expenditure paths without having to rely on pure signalling effects.

In Chadha et al. (2013a), we explored the advantages to the representative household from using money as an indicator, particularly when it covaries negatively with market interest rates, EFP. This is because when the money supply process is dominated by supply shocks, the EFP and money supply tend to move in opposite directions. And this will tend to set-up output and inflation variances that may be missed by a simple feedback rule related to standard inflation targeting practice. We examined an illustrative calculation in a model of money supply via a loans production function, in which the economy is better stabilised when the correlation between money and interest rates is driven to zero, that is when the information content from money supply is exploited by the policy maker. As a by-product, we can understand why money may not have much information for activity in an economy when the central bank has acted to stabilise activity well. We need then to consider how money, inside or outside the private sector can be created and for what reason it is held.

The Chadha-Corrado model, is an extension of the Goodfriend-McCallum model (2007),

\footnotetext{
${ }^{14}$ See Chadha et al, 2013b for the implications for US bond yields from supply effects.
} 
in which credit constrained consumers require loans from a commercial bank in order to effect their planned consumption paths. The bank employs a loans production technology with arguments in the value of collateral and the employment of workers who monitor loans and also has to respect a liquidity constraint in deciding on the optimal levels of the reservedeposit ratio. The commercial bank's liabilities can thus be funded by a mix of interest rate paying reserves and external finance premium paying loans. Chadha and Corrado (2012) and Chadha et al. (2012) find that in this framework, banks can use reserves as a buffer against costly changes in monitoring costs and so can choose to alleviate some of the counter-cyclical variation in the external finance premium. So we examine the implications from increasing the reserve ratio by some $7 \%$ in this model.

The fall in output following a large negative demand shock is, in this case, can be some $15 \%$. After which inflation falls by around $6 \%$ with real wages and employment both falling by something more than $20 \%$ and in this case the increase in monitoring effort by commercial banks puts upward pressure on the external finance premium. The increased issuance of bonds by the government, which tries to stabilise output also pushed up liquidity premia on bonds. In the two cases where the reserve-deposit ratio is not fixed but chosen endogenously by commercial banks, the contractionary shock leads to an increase in demand for reserves, which are supplied perfectly elastically by the central bank. This increase in reserves, analogous to an increase in the central bank balance sheet, acts to limit the increase in the costs of loans supply, because banks hold reserves ex ante against potential problems with loans. Liquid reserves offset some of the upward shock to interest rates spreads and can mitigate around $30-40 \%$ of the shock in this model. There has been some work examining the impact of QE by the Fed on India, for example Banerjee and Basu (2016) who concentrate on the spillover effects for India via a terms of trade and UIP channel. Clearly overseas economies may impact shocks on India. But we though are more interested in the analysis of the appropriate domestic monetary policy options for India, which may include active interest rates, as well as some role for the expansion or contraction of the central bank balance sheet.

\section{A DSGE Model of Money and Banking}

In this section, we will examine a DSGE model that differs from the 'plain vanilla' New Keynesian case by having more than one interest rate. A plain vanilla model would have as its New Keynesian core a forward-looking household and firm, optimising their profit and consumption stream, subject to sticky prices and with central bank operations conducted under an active interest rate rule. In this model, we shall in addition have one or more interest rates impact on aggregate demand and these will have some additional traction on the economy. We shall keep my exposition of the microfoundation devices to a minimum 
and encourage reading of the original papers for further details. The creation of models with more than one interest rate means that the short term interest rate performs as an approximate control device at all times and an especially problematic one when the zero lower bound, or some other constraint, acts to constrain the interest rate path. The model is a variant of Goodfriend and McCallum (2007) developed by Chadha and Corrado (2012), consumers are deposit constrained and banks choose a mix of lending and reserves holding to meet a given level of deposit demand. We also allow investment in this version of the model, which is allocated through the same loan production function and incurs some costs in implementation. Banks produce loans for consumption and investment using a combination of the value of collateral, monitoring workers and also have preference for liquid reserves. Reserves act as a cushion against hiring and firing of monitoring workers and thus can attenuate movements in the external finance premium, which is essentially the marginal costs of loans supply.

\subsection{A Model of Money and Banking}

The model is a (Calvo-Yun) monopolistically competitive economy with sticky prices and four main agents; households, who can work either in the goods producing sector or in the banking sector monitoring loan quality and produces wholesale goods and retail goods, banks, who meet consumer deposit demand via reserves and a loans production function, and the monetary authority. Households divide their time between working in goods or loan production and leisure. They consume up to the value of their deposits, invest on behalf of the firm they own, take on loans and hold other assets of bonds and capital. Commercial banks hold reserves and create loans to equal the quantity of deposits held by households. The government, which issues bonds and backs interest rate payments with lump sum taxation on households - we do not develop an active version of fiscal policy here and simply assume some steady state level of public debt. The central bank holds some of the outstanding stock of bonds and used that to back its issuance of reserves, or central bank money. Figure 3 sets out the relationships between these three sectors in this model.

\subsection{Households and Firms}

The household plan are constrained by the quantity of deposits in the representative commercial bank. The households decide on their consumption, investment (as owners of the firm) and labour supply to production sector and banking sector during period $t$. Households demand deposits because the consumption and investment decision is made at the beginning of period $t$ and income is determined (realised) at the end of period $t$. Banks therefore lend to fund consumption and investment. Throughout we assume that there are one-period 
deposits, loans and government bonds.

The household maximises the expected present value of its expected utility, $U_{t}$ :

$$
\max U_{t}=E_{0} \sum_{k=0}^{\infty} \beta^{t}\left[\phi \log \left(c_{t}\right)+(1-\phi) \log \left(1-n_{t}^{s}-m_{t}^{s}\right)\right]
$$

where $c_{t}$ is consumption expenditures in period $t, n_{t}^{s}$ is supply of labour to the production of goods, $m_{t}^{s}$ is labour monitoring work in the banking sector subject to the following three constraints.

The household budget constraint (Lagrangian multiplier, $\lambda_{t}$ ) acts on flow income. The household source of funds is comprises: (i) deposits and bonds from previous period, (ii) wages from their labour (iii) sales of physical capital (iv) sales of goods. Households use their funds for (i) holding deposits (ii) purchasing bonds and capital (iii) paying for wages and taxes (iv) paying for their consumption expenditures.

$$
\begin{aligned}
\frac{D_{t-1}}{P_{t}}+\frac{B_{t}}{P_{t}}+q_{t}(1-\delta) K_{t}+w_{t}\left(n_{t}^{s}\right. & \left.+m_{t}^{s}\right)+y_{t}\left(\frac{P_{t}^{W}}{P_{t}}\right)^{1-\epsilon} \\
& =\frac{D_{t}}{P_{t}^{A}}+\frac{B_{t+1}}{P_{t}\left(1+R_{t}^{B}\right)}+q_{t} K_{t+1}+w_{t}\left(n_{t}+m_{t}\right)+\operatorname{tax}_{t}+c_{t}
\end{aligned}
$$

where $q_{t}$ is the real price of capital, $K_{t}$ is the capital at start of $t, D_{t}$ is households' deposits, $P_{t}^{W}$ is wholesale good price, $P_{t}$ is the aggregate price index, $n_{t}^{s}$ is the labour supplied to the firms by households, $m_{t}^{s}$ is the labour supplied to banking sector, $w_{t}$ is the real wage rate, $n_{t}$ and $m_{t}$ is the labour demanded by firms and banking sector. $R_{t}^{D}$ is nominal deposit interest rate, $R_{t}^{B}$ is nominal interest rate on government bonds purchased in $t$ and redeemed in $t+1$, $\epsilon$ is the elasticity of differentiated goods, $\operatorname{tax}_{t}$ is the real lump-sum tax payment.

In addition, households have the constraint that deposits are held in advance (Lagrangian multiplier, $\left.\mu_{t}\right)$. Household consumption and investment during the period $t$ is constrained to the quantity of deposits:

$$
y_{t}=c_{t}+I_{t}=\frac{v_{t} D_{t}}{P_{t}}
$$

where $v_{t}$ is the velocity of deposit circulation, $D_{t}$ is deposits. The impact of velocity changes will be introduced later as a measure of financial inclusion (Khan and Thomas, 2014).

\subsection{Firms}

\subsubsection{Wholesale Goods Producer}

As is standard in New Keynesian models, we adopt both a constant returns to scale CobbDouglas production function and assume that the wholesale goods producer operates under 
monopolistic competition and seeks to minimise the costs of production posts prices subject to Calvo pricing. The Cobb-Douglas production is subject to labour-augmenting efficiency shocks, $A 1_{t}$, with shares of capital and labour given by $\eta$ and $1-\eta$, respectively.

Firms decide the amount of production they wish to supply and the demand for labour by meeting the sales equal to net production (Lagrangian multiplier: $\xi_{t}$ ):

$$
K_{t}^{\eta}\left(A 1_{t} n_{t}\right)^{1-\eta}=y_{t}\left(\frac{P_{t}^{W}}{P_{t}}\right)^{-\epsilon}
$$

By clearing the household and production sector, we can define the equilibrium in the labour market and in goods market.

$$
\begin{gathered}
\frac{1-\phi}{1-n_{t}^{s}-m_{t}^{s}}=w_{t} \lambda_{t} \\
w_{t}=\frac{\xi_{t}}{\lambda_{t}}(1-\eta) \frac{y_{t}}{n_{t}}
\end{gathered}
$$

And we employ a standard law of motion for capital considering an investment adjustment cost, $S(\cdot)$ in this model:

$$
K_{t+1}=(1-\delta) K_{t}+\left[1-S\left(\frac{I_{t}}{I_{t-1}}\right)\right] I_{t}
$$

where $S\left(\frac{I_{t}}{I_{t-1}}\right)=\frac{s}{2}\left(\frac{I_{t}}{I_{t-1}}-(1+\varrho)\right)^{2}, S(1+\varrho)=S^{\prime}(1+\varrho)=0, S^{\prime \prime}(1+\varrho)=s>0, \varrho$ is a trend growth rate.

\subsubsection{Final Good Producer (Retailer)}

Final goods are produced using a variety of intermediate goods, which allows us to derive the standard New Keynesian Phillips curve. To which we append both backward and forwardlooking behaviour to capture the behaviour of price setters in rule of thumb settings. The derivation of the price of goods results from the Calvo pricing mechanism:

$$
\sum_{s=0}^{\infty} \theta^{s} E_{t}\left[\Lambda_{t, s} Y_{t, t+s}\left(\frac{P_{t}^{f}}{P_{t-1}}-\mathrm{X}_{\psi} \mathrm{mc}_{\mathrm{t}} \pi_{\mathrm{t}-1, \mathrm{t}+\mathrm{s}}\right)\right]=0
$$

where only $1-\theta$ share of firms can reset their price per period, $P_{t}^{f}$ is forward looking firm optimal price (resetting price), $\Lambda_{t, s}=\beta^{s}\left(\frac{c_{t+s}}{c_{t}}\right)^{-1}\left(\frac{P_{t}}{P_{t+s}}\right)$ is the households' stochastic discount factor, $X_{\psi}=1 / m c$ is desired markup. $m c_{t}$ is real marginal cost, and $\pi_{t-1, t+s}=\frac{P_{t+s}}{P_{t-1}}$. The aggregate price level is thus given by: 


$$
P_{t}=\theta P_{t-1}+(1-\theta) \bar{P}_{t}^{*}
$$

where $\bar{P}_{t}^{*}$ is an index of prices set in period $t$ based on the forward-looking and backwardlooking price setting behaviour such that:

$$
\bar{P}_{t}^{*}=\omega P_{t}^{b}+(1-\omega) P_{t}^{f}
$$

where $P_{t}^{b}$ is the price set by the backward-looking rule of thumb $\left(P_{t}^{b}=\bar{P}_{t-1}^{*}+\pi_{t-1}\right), P_{t}^{f}$ is the fraction of the price set by on a forward-looking basis, and $\omega$ measures the degree of backward-looking price setting behaviour. Hybrid New Keynesian Phillips Curve is given by

$$
\pi_{t}=\kappa m c_{t}+\gamma_{f} E_{t}\left(\pi_{t+1}\right)+\gamma_{b} \pi_{t-1}
$$

\subsection{Government Sector}

The government faces a per period government budget constraint in which any excess of government expenditure will be financed by the issuance of bonds and central bank money. The government issues bonds to the household or supplies reserves to commercial banks at differentiated interest rates. We will use two version of our model: one in which the issuance of reserves does not bear interest $\left(R_{t}^{I B}=0\right)$ and remains a fixed fraction of the overall level of deposits, secondly, where there is some interest paid on reserves $\left(R_{t}^{I B}=R_{t}>0\right)$ and as a consequence, the commercial bank optimises on the fraction of deposits held as reserves.

$$
g_{t}-\operatorname{tax}_{t}=\frac{r_{t}}{P_{t}\left(1+R_{t}^{I B}\right)}-\frac{r_{t-1}}{P_{t}}+\frac{B_{t+1}}{P_{t}\left(1+R_{t}^{B}\right)}-\frac{B_{t}}{P_{t}}=0
$$

where $g_{t}$ is the government expenditures, $\operatorname{tax}_{t}$ is the tax receipt, $B_{t}$ is government bond, $r_{t}$ is banks' reserves, $R_{t}^{I B}$ is supposed to be equal to policy rate, $R_{t}$. For simplicity, we will also use. $r e_{t}=\frac{r_{t}}{P_{t}\left(1+R_{t}^{I B}\right)}$ and $b_{t+1}=\frac{B_{t+1}}{P_{t}\left(1+R_{t}^{B}\right)}$. There are in effect two types of government liabilities, reserves which attract the policy rate (akin to T-bills) or zero interest rate (akin to currency) or bonds which attract the benchmark interest rate minus their liquidity service yield. The reserves are held by banks as part of their assets and bonds are held by households and may be posted as collateral in order to obtain loans. 


\subsection{Banking Sector}

\subsubsection{The Demand and Supply of Deposits}

The commercial bank balance sheet is given by:

$$
L_{t}+r_{t}=D_{t}
$$

where $L_{t}$ is nominal loans, $r_{t}$ is nominal reserves, $D_{t}$ is nominal deposits at the end of $t$. The household has a demand for deposits, as a deposit-in-advance constraint, which is given by:

$$
c_{t}+I_{t}=\frac{v_{t} D_{t}}{P_{t}}
$$

and the derived demand for deposits (broad money) can be written as:

$$
D_{t}^{d}=\frac{P_{t} y_{t}}{v_{t}}
$$

The commercial bank supply for deposits can be expressed from bank balance sheet constraint:

$$
D_{t}^{s}=\frac{L_{t}}{1-r r_{t}}
$$

where $r r_{t}=\frac{r_{t}}{D_{t}}$ is the reserve-deposit ratio.

\subsubsection{Loan Production and the Broad Liquidity Constraint}

The commercial bank meets the demand for households deposits by producing loans. Assuming that there are information frictions in lending markets (e.g. asymmetric information), we assume that loans are created by Cobb-Douglas loans production function with inputs of collateral and bank monitoring (or screening) effort.

$$
\frac{L_{t}}{P_{t}}=F \underbrace{\left(b_{t+1}+A 3_{t} k q_{t} K_{t+1}\right)^{\alpha}}_{\text {collateral }}\left(A 2_{t} m_{t}\right)^{1-\alpha} \quad 0<\alpha<1
$$

Collateral comprises (real) government bonds $b_{t+1}\left(=\frac{B_{t+1}}{P_{t}\left(1+R_{t}^{B}\right)}\right)$ and capital $K_{t+1}$ posted by households which is inferior as collateral relative to bonds, $q_{t}$, is the price of capital, $K_{t+1}$ is capital at end of $t, k$ is an inferiority of capital as collateral relative to bonds, $A 3_{t}$ is collateral shock (asset price shock). The second argument in the production function comprises $m_{t}$, which is employment in loan monitoring and $A 2_{t}$, which is a monitoring productivity shock. The coefficient, $F$ measures the efficiency with which inputs are turned in loans. 
By placing the loans production function into the deposit supply, we can express a broad liquidity constraint as a function of the DIA condition, the bank balance sheet and the loan production function:

$$
y_{t}=v_{t} \frac{F\left(b_{t+1}+A 3_{t} k q_{t} K_{t+1}\right)^{\alpha}\left(A 2_{t} m_{t}\right)^{1-\alpha}}{1-r r_{t}} \quad 0<\alpha<1 .
$$

We can derive the equilibrium of the labor demand in banking sector:

$$
w_{t}=\frac{\mu_{t}}{\lambda_{t}} \frac{(1-\alpha) y_{t}}{m_{t}}
$$

\subsubsection{Reserves}

The commercial bank can either hold a fixed fraction of its overall deposit as reserves or be allowed to vary the ratio in an optimised manner. Following Chadha and Corrado (2012) banks seek to maximize total returns within period subject to the returns from loans, $L_{t}$, which are lent out at the interest rate of $R_{t}^{L}$, the cost or return of obtaining reserves, $R_{t} r_{t}$, and the payment of deposit interest, $R_{t}^{D} D_{t}$, to deposits:

$$
\begin{aligned}
& \max _{r_{t}} \Pi_{t}=R_{t}^{L}(\underbrace{D_{t}-r_{t}}_{L_{t}})+R_{t}^{I B} r_{t}-R_{t}^{D} D_{t} \\
& \text { s.t. } \quad C_{t}^{r}=\frac{1}{2} R_{t}^{T}\left(\bar{r}-r_{t}\right)^{2}+\tau_{t}\left(\bar{r}-r_{t}\right)
\end{aligned}
$$

Commercial bank profits are also subject to a side constraint motivated by concerns over reserve management. We assume that banks have an exogenous target for the level of reserves, $\bar{r}$, perhaps set by custom and practice or by legislation. ${ }^{15}$ We assume that any deviation from this target imposes two costs on the bank. The first is symmetric and derives from the bank's desire to smooth the path of reserves and avoid any sharp swings in its asset position as these may signal mismanagement and result in reputational loss. In the model the cost of such deviations from target is the uncollateralised interest rate, $R_{t}^{T}$. This is because if $r_{t}<\bar{r}$, the commercial bank will fund its shortfall at the penalty rate, and if $r_{t}>\bar{r}$ the commercial bank will have missed the opportunity to lend out those reserves at the same penalty rate and thus incurs the opportunity cost, $R_{t}^{T}$.

The second term relates to the need of commercial banks to hold a certain level of reserves to meet its desired reserve target in any given period. Whilst exogenous in this framework, this target is most likely driven by the level of required reserves set by the

\footnotetext{
${ }^{15}$ In practice, most major economies have a minimum level of required reserves relative to depositis. Our long run target for India is set at $20 \%$.
} 
regulator (Basel III, 2010), although banks may set a target in excess of this minimum limit if they have heightened precautionary motives for holdings safe, liquid assets, such as central bank reserves. Therefore, the second term can be thought of as an exogenous shift in the ex-ante probability of a reserve shortfall or analogously an shift in the demand for reserves. Solving with respect to reserves, and assuming the interest on reserves model, the optimal, profit-maximizing level of reserves gives us the commercial bank demand curve and can be written as:

$$
r_{t}=\bar{r}+\left[\frac{R_{t}^{I B}-R_{t}^{L}}{R_{t}^{T}}\right]+\frac{\tau_{t}}{R_{t}^{T}} .
$$

It is a positive function of the probability, $\tau_{t}$ of the commercial bank being short its obligated level of reserves, $\bar{r}$, and positive in $R_{t}^{I B}$, and negative in, $R_{t}^{L}$, which is respectively the return on reserves and the opportunity cost of reserves i.e. the loan rate. We therefore emphasize that the relative cost and returns of the two mechanisms of meeting deposit demand change, so do the bank's optimal quantities of each.

Figure 4 illustrates the implications of changing the return on reserves for the commercial bank choice of reserve-deposit ratio. For a given quantity of deposits, which corresponds to a given fraction of lending and reserves, each asset yields a overall return at its interest rate. If the ratio of reserves to deposits is fixed then for a higher or lower level of deposits the bank's asset allocation will lie on the black expansion path. But if there are changes in the return on reserves, the slope of the isoquant line will change and the composition of the optimal portfolio will change. If the bank does not change the composition of its assets, it will not be maximising profits. In general equilibrium, the bank will then have an incentive to change its loan rates and this will tend to inject volatility into the economy.

\subsection{Market Interest Rates}

The model produces a variety of market interest rates that are determined by the implicit service yield from each type of loan contract (See Table 1). As in Goodfriend and McCallum (2007) we start with a benchmark riskless interest rate that introduces a one-period defaultfree security that provides no collateral services to its holders. This benchmark rate bears a shadow 'total' return that represents the pure intertemporal rate of interest, which (= risk adjusted pecuniary + service yields on other assets) must be matched by other assets. That is, the bank would be willing to loan funds to the household, if it incurred all necessary costs to match the benchmark rate $R_{t}^{T}$.

From the perspective of household optimization problem, the benchmark riskless interest 
rate $R_{t}^{T}$ is defined as:

$$
1+R_{t}^{T}=\beta E_{t} \frac{\lambda_{t} P_{t+1}}{\lambda_{t+1} P_{t}}
$$

The interest rate on bonds $R_{t}^{B}$ is lower than $R_{t}^{T}$ due to the liquidity service yield $\left(L S Y_{t}^{B}\right)$ on bonds. (by $\frac{\partial \mathcal{L}}{\partial B_{t+1}}=0$ )

$$
R_{t}^{T}-R_{t}^{B}=\frac{\mu_{t}}{\lambda_{t}} \Omega_{t}=L S Y_{t}^{B}
$$

where $\frac{\mu_{t}}{\lambda_{t}}=\frac{\phi}{c_{t}}-1$, measures the households' marginal utility relative to households shadow value of funds while $\Omega_{t}$ is the marginal value of bond-collateralised lending.

The marginal value of bond for collateralised lending $\left(\Omega_{t}\right)$ is given by

$$
\frac{\partial y_{t}}{\partial b_{t+1}}=\frac{\alpha y_{t}}{b_{t+1}+A 3_{t} k q_{t} K_{t+1}}
$$

The liquidity service yield on capital $\left(L S Y_{t}^{K}\right)$ is

$$
L S Y_{t}^{K}=k \times L S Y_{t}^{B}
$$

where $k$ is an inferiority of capital as collateral relative to bonds.

\subsection{External Finance Premium}

Here, we assume that the collateral costs are borne by the bank. The commercial bank can obtain (borrow) funds in the interbank market at interbank rate, or policy rate, $R_{t}^{I B}$. The external finance premium, $E F P_{t}$, can be regarded as the gap between the uncollateralised loan rate $R_{t}^{T}$ and the cost of loanable funds $R_{t}^{I B}$. This external finance premium reflects the real marginal cost of loan production. From the cost-minimising optimal mix of factor inputs, the real marginal cost of loan production, $m c l_{t}$, is the factor price $\left(w_{t}\right)$ divided by the marginal product of monitoring work in the loan production $\left(\right.$ mpm $\left._{t}\right)$. Note that workers whether they work in goods production or monitoring are paid the same wage.

$$
\begin{aligned}
m c l_{t} & =\frac{w_{t}}{m p m_{t}} \\
m p m_{t} & =(1-\alpha) \frac{L_{t}}{P_{t} m_{t}}=(1-\alpha) \frac{\left(1-r r_{t}\right) D_{t}}{P_{t} m_{t}}=(1-\alpha) \frac{(1-r r) y_{t}}{V_{t} m_{t}} \\
U E F P_{t} & =m c l_{t}=\frac{w_{t} v_{t}}{(1-\alpha)(1-r r) y_{t}}=\frac{\mu_{t}}{\lambda_{t}} \frac{v_{t}}{\left(1-r r_{t}\right)} \\
C E F P_{t} & =(1-\alpha) U E F P_{t}=\frac{w_{t} v_{t} m_{t}}{(1-r r) y_{t}}=\frac{\mu_{t}}{\lambda_{t}} \frac{v_{t}(1-\alpha)}{\left(1-r r_{t}\right)}
\end{aligned}
$$


The EFP $P_{t}$ reflects the real marginal cost of loan production and has two forms: uncollateralised, $U E F P_{t}$, and collaterised, $C E F P_{t}$. In effect, the uncollateralised loan rate is equated to $R_{t}^{T}$ as it comprises the policy rate and the premium.

We can show that the external finance premium interacts with both the demand $\left(c_{t}+I_{t}\right)$ and supply factor of money $\left(D_{t}\right)$ and bank balance sheet condition $\left(r r_{t}\right)$. Most loans are collateralised with assets (government bonds and capital) and therefore the loan rate $\left(R_{t}^{L}\right)$ is lower than the benchmark rate $R_{t}^{T}$ by the liquidity service yield from assets.

The deposit rate is simply:

$$
R_{t}^{D}=R_{t}^{I B}\left(1-r r_{t}\right)
$$

so that as the ratio of reserves to deposits rises as the commercial bank pays a lower return to depositors.

\subsection{Monetary Policy and Fiscal Policy}

We suppose that the central bank changes its policy rate (interbank rate) in response to inflation and output in standard fashion.

$$
\widehat{R}_{t}^{I B}=\rho \widehat{R}_{t-1}^{I B}+(1-\rho)\left(\phi_{\pi} \widehat{\pi}_{t}+\phi_{y} \widehat{y}_{t}+\phi_{f} \widehat{f}_{t}\right)
$$

Under the standard interest rate reaction function, $\phi_{f}=0$. But in a later simulation we will assess what happens when the policy maker feeds back from financial conditions, which we proxy by:

$$
\widehat{f_{t}}=\left(\frac{L_{t}}{P_{t}}-e f p_{t}\right),
$$

where a demand for more loans from optimal increases in investment or consumption will tend to lead to a limited response by the policy maker because loans and the external finance premium will rise together. But when the financial sector itself changes the extent of its activity by shifting its supply, then loans and the external finance premium will move negatively and so there will be a strong response by the policy maker.

We characterise fiscal policy as simply a stationary target for the government bond to GDP ratio, boyt:

$$
\widehat{b o y}_{t}=a 6_{t}=\rho_{b o y} \widehat{b o y}_{t-1}+\epsilon_{t}^{b o y} .
$$




\section{$5 \quad$ Results}

We calibrate this model to Indian data and solve using standard techniques. The model is solved under three separate scenarios. A standard NK model with government debt stable and an active interest rate but with no explicit monitoring of financial conditions. The alternate solution retains the active interest rate rule but also allows the commercial bank to vary its demand for reserves and the central bank to meet that demand. The third solution allows the central bank to respond to supply shocks in bank lending under either of a fixed or variable reserves regime with an augmented interest rate reaction function. We examine a number of impulse responses of key endogenous state variables to the model's shocks under the two solutions, as well as an example of the data generated from the two basic cases. Then we assess the moments of the model and approximate the welfare of the household.

\subsection{Calibration}

Table 2 reports the values for the parameters and Table 4 the steady-state values of relevant variables. ${ }^{16}$ Following Goodfriend and McCallum (2007) we choose the consumption weight in utility, $\phi$, of 0.4 mark available time in either goods or banking services production. Labour share is 0.6 from Gabriel et al (2012). We also set the relative share of capital and labour in goods production $\eta$ to be 0.4 . We choose the elasticity of substitution of differentiated goods, $\epsilon$, to be equal to 6 . The discount factor, $\beta$, is set to 0.98 which is close to the canonical quarterly value while the mark-up coefficient in the Phillips curve, $\kappa$, is set to 0.24 (Goyal, 2014). The depreciation rate, $\delta$, is set to be equal to 0.025 while the trend growth rate, $\varrho$, is set to 0.125 which corresponds to $5 \%$ per year. The steady-state value of bond holding level relative to GDP, $b$, is set to 0.75 as of the third quarter of $2005 .{ }^{17}$

The deep parameters linked to money and banking are defined as follows. Ratio of Nominal GDP to M3 in India has averaged 1.7 since 1990. The fractional reserve requirement, $r r$, is set at 0.2 , which is just below the RBI's statutory liquidity ratio of just over $20 \%$. This leaves us three key deep parameters to manipulate which may influence the rest of the steady state variables. Interestingly these are three financial variables and so are of particular interest to our debate on policies. $\alpha$ is the Cobb-Douglas weight of collateral in loan production. This is the degree to which banks base their lending on collateral as opposed to monitoring work or information based lending. The benchmark calibration of 0.7 is taken from Calomiris et al (2015). $k$, is the degree to which capital is less efficient as collateral than bonds as it entails higher costs to the bank in order to check its physical condition and

\footnotetext{
${ }^{16}$ The equations for the steady-state equations are listed in the technical appendix.

${ }^{17}$ The steady state of the transfer level, the Lagrangian of the production constraint and base money depend on the above parameters. The steady state of the marginal cost is $m c=\frac{\epsilon-1}{\epsilon}$.
} 
market price. It is also less liquid should default occur and the collateral be called upon to repay the value of the loan. We set this parameter to 0.2 which follows Goodfriend and McCallum (2007). F, can be thought of as total factor productivity in loan production, or a measure of the efficiency with which banks use the factors of production to produce loans. ${ }^{18}$ We end up with a $5.6 \%$ per year average real short-term rate; a $2.3 \%$ average collateralized external finance premium that is broadly in line with the average spread of the prime rate over the policy rate and with some $4 \mathrm{mn}$ employed in banks from labour force of over 500mn, so let's choose something around $1 \%$ for the share of employment in banking, we choose $1.3 \%{ }^{19}$ The steady-state value this yields is $F=3.9$.

With these parameter values we see that the steady state of labour input, $n$, is 0.35 which is close to $1 / 3$ as required. As the steady-states are computed at zero inflation we can interpret all the rates as real rates. The benchmark rate, $R^{T}$, is $13 \%$ per annum. The interbank rate, $R^{I B}$, is $5.6 \%$ and the government bond rate, $R^{B}$, is $9.8 \%$ per annum. Finally the collateralized external finance premium is $2.3 \%$ per annum which is in line with the average spread of the prime rate over the policy rate in the emerging economies.

\subsection{Solution Method}

The benchmark model has 27 endogenous variables $\left\{c, n, y, m, w, K, I, q, P, \pi, \pi_{t-1}, m c, H, b, \Omega, E F P\right.$, $\left.R^{T}, R^{B}, R^{I B}, R^{L}, R^{D}, \lambda, \mu, \xi, T, r, r e\right\}, 9$ lagged variables $\left\{P_{-1}, H_{-1}, c_{-1}, b_{-1}, r e_{-1}, R_{-1}^{B}, y_{-1}, K_{-1}, I_{-1}\right\}$ and 8 exogenous shocks $\{a 1, a 2, a 3, a 4, a 5, a 6, a 7, a 8\}$, see Table 4 . The equations (83) through (108), 9 lagged identities construct the model to be solved by King and Watson (1998) algorithm. For the simulation we consider contemporaneous shocks to $a 1, \ldots, a 8$. To obtain the simulated series we have produced 5,000 draws from a normal distribution, discard the first 250 and considered the middle 100. For the impulse response analysis and simulation exercise we consider the real and financial shocks described in Table 4, which reports the volatility and persistence parameters chosen for the calibration and simulation exercise. These are standard parameters in the literature. The model is then solved using the solution methods of King and Watson (1998) to derive the impulse responses of the endogenous variables to different shocks, to obtain asymptotic variance and covariances of the variables and to simulate the data. This system of linear difference equations can be expressed as a singular dynamic system of the following form:

$$
\check{\mathbf{A}} E_{t} \mathbf{y}_{t+1}=\check{\mathbf{B}} \mathbf{y}_{t}+\check{\mathbf{C}} \varepsilon_{t} \quad \forall t \geq 0,
$$

\footnotetext{
${ }^{18}$ Some authors have also described it as a measure of credit conditions within the economy. The rationale for this seems plausible as when credit conditions are tight, banks will require more collateral and will employ more monitoring work to provide the same amount of loans to the economy.

${ }^{19} \mathrm{http}: / /$ www.slideshare.net/iimjobs/india-banking-sector-report-april-2014. (Reserve Bank of India)
} 
where $\mathbf{y}_{t}$ is the vector of endogenous variables comprising both predetermined and nonpredetermined variables including policy rules for the nominal interest rate, $\varepsilon_{t}$ is a vector of exogenous forcing variables, and $\check{\mathbf{A}}, \check{\mathbf{B}}$ and $\check{\mathbf{C}}$ are matrices of fixed, time-invariant, coefficients. $E_{t}$ is the expectations operator conditional on information available at time $t$. King and Watson (1998) demonstrate that if a solution exists and is unique then we may write any such solution in state-space form as follows,

$$
\begin{aligned}
\mathbf{y}_{t} & =\boldsymbol{\Pi} \mathbf{s}_{t} \\
\mathbf{s}_{t} & =\mathbf{M} \mathbf{s}_{t-1}+\mathbf{G e}_{t},
\end{aligned}
$$

where the $\mathbf{s}_{t}$ matrix includes the state variables of the model (predetermined variables along with exogenous variables), $\mathbf{e}_{t}$ is a vector of shocks to the state variables and $\mathbf{\Pi}, \mathbf{M}$ and $\mathbf{G}$ are coefficient matrices. There are eight shocks in $\mathbf{G}$ and the variance-covariance as well as the autocorrelation matrices associated with these shocks are described in Table 4. The impulse responses of this system are given by:

$$
\begin{aligned}
E_{t} \mathbf{y}_{t+k}-E_{t-1} \mathbf{y}_{t+k} & =\boldsymbol{\Pi}\left(E_{t} \mathbf{s}_{t+k}-E_{t-1} \mathbf{s}_{t+k}\right) \\
& =\mathbf{M}^{k} \mathbf{G e}_{t}
\end{aligned}
$$

And the variance of the states, $\mathbf{V}_{s s}$, is given by:

$$
\operatorname{vec}\left(\mathbf{V}_{s s}\right)=(\mathbf{I}-\mathbf{M} \otimes \mathbf{M})^{-1} \operatorname{vec}\left(\mathbf{G} \mathbf{V}_{e e} \mathbf{G}^{T}\right)
$$

\subsection{Impulse Response Functions}

Figures 7-10 shows the endogenous responses of key state variables to four of the eight shocks we have considered in the model. ${ }^{20}$ In response to an increase in productivity, a fixed reserve-deposit ratio leads to a greater increase in the EFP, which acts to lead to lower output and inflation than when reserves are allowed to increase and the increase in the EFP is attenuated. In the latter case, output increases by more and inflation falls by less. Figure 8 shows the impact of an increase in the productivity of bank loan production, which acts like an aggregate demand shock - raising output and inflation. When the reserve ratio is

\footnotetext{
${ }^{20}$ The other four shock IRFs are available on request.
} 
allowed to move, the commercial bank does not shed as much labour in loans production and this means that the external finance premium does not fall as much, acting again to attenuate the impact on output and inflation. Figure 9 shows the impact of a collateral, or asset price shock, and because it is an argument in the loans production function, it has a very similar impact to the efficiency of loan production - having higher value collateral allows the bank to shed expensive monitoring labour and drive down the EFP - but this effect will be limited if central bank meets the demand for reserves instead. Finally, with a positive monetary policy shock, the commercial bank may choose to hold more reserves and this will tend to limit the impact on the external finance premium.

We should treat variation in the reserve-deposit ratio, as the counterpart to changes in the size of the central bank balance sheet over the business cycle and this seems quite clearly to act in a stabilising manner compared to an interest rate rule alone. Even though we have a closed economy model, clearly the Reserve Bank of India could expand or contract its balance sheet with respect to domestic and/or foreign assets.

\subsection{Table of Moments and Welfare}

Having calibrated and simulated the model, we show in Table 5 the moments from the model where there is a fixed reserve ratio and where we allow commercial banks and the central bank to set the appropriate level of reserves. In this model, consumption and investment move with the business cycle, albeit where investment is significantly more volatile than consumption, as we would expect. Note that asset prices are procyclical and market interest rates are countercyclical. The latter results suggests that the amplification effect of asset prices leading to lower market interest rates dominates any attenuation effect whereby increased demand for loans in an upswing places upward pressure on market interest rates. With endogenous reserves, inflation becomes less volatile and broadly acyclical. Note also that under this regime, real wages, asset prices and the external finance premium become significantly less volatile.

\subsection{Welfare Analysis}

Having discussed in the previous section why variance in the reserve-deposit ratio can improve welfare over the cycle we seek to strengthen this result by quantifying its impact on the representative household. To do this we carry out some more stringent welfare analysis by deriving a welfare loss function from a second order approximation to utility. 


\subsubsection{Deriving The Welfare Loss Function}

The welfare approximation derived from the canonical New Keynesian model finds that welfare of the representative household only depends on the variance of output and inflation (Galí, 2008). The use of the approximation allows us to quantify precisely the welfare rankings arising from each of our policy rules, possibly allowing some normative statements. Thus, we derive a quadratic loss function using a second-order Taylor approximation to utility by using the labour demand function, marginal cost function and sales-production constraint to substitute for household consumption. ${ }^{21}$ Once re-ordered and simplified we are left with a loss function with relevant terms in the variances of consumption, inflation, wages, employment in the goods sector and the marginal cost.

$$
\begin{aligned}
U_{t}-U & =-\frac{1}{2} E_{0} \sum_{t=0}^{\infty} \beta^{t} L_{t}+O 3 \\
\text { with } L_{t} & =\frac{1}{2}\left[\begin{array}{c}
\sigma_{c}^{2}+\frac{\theta}{\chi}\left[\frac{\frac{n}{c}-\frac{w}{c}}{1-\eta}\right] \sigma_{\pi}^{2}- \\
\frac{w}{c} \sigma_{w}^{2}-\frac{n}{c} \sigma_{n}^{2}+\frac{m c}{c} \sigma_{m c}^{2}
\end{array}\right],
\end{aligned}
$$

where $\chi=\frac{(1-\epsilon)(1-\beta \epsilon)}{\epsilon} \frac{1-\eta}{1+\eta(\epsilon-1)}$. Given that $\frac{w}{c}>0$ and $\frac{n}{c}>0$, more flexible wages and employment improves welfare, whilst $\frac{m c}{c}>0$ and $\frac{\epsilon}{\chi}\left[\frac{\frac{n}{c}-\frac{w}{c}}{1-\eta}\right]>0$, so more stable marginal cost, consumption and inflation improves welfare.

The results of the welfare analysis given in Table 6 are stark. Compared to a fixed reserve ratio, allowing commercial banks to choose their ratio of reserves to deposits is welfareenhancing for the representative household under a normal regime or one where banking shocks dominate e.g. after a reform in or liberalisation of the banking system. ${ }^{22}$ Rather than allowing reserves to be endogenous, using an augmented rule by responding to the difference between credit and financial spreads also seems to improve welfare, by reducing losses, relative to a standard interest rate reaction function. But an augmented rule has little advantage when reserves are endogenous unless banking shocks dominate, and then perhaps to a small degree. Augmenting the interest rate reaction function by responding to financial conditions does also seem to improve performance both when reserves are fixed and when banking shocks dominate. We conclude that relative to the standard interest rate reaction

\footnotetext{
${ }^{21}$ The additive nature of our household's utility function allows us to take a Taylor expansion of each term and substitute it back into the original function. The labour demand function is then rearranged for monitoring work, a second order expansion taken and substitution made. This process is then repeated for the marginal cost equation. Following Galí (2008) we substitute the resulting linear term in goods sector employment for a second order term in inflation using the sales equal net production constraint.

${ }^{22} \mathrm{~A}$ referee suggested rightly that we re-run these calculations for different choices of deep parameters, but we have undertaken this kind of analysis elsewhere using advanced country calibrations and obtained qualitatively similar results.
} 
function, the modelling of financial frictions implies that more sophisticated monetary policy actions may be required than a standard active interest rate rule. We have not undertaken a full-blown optimality analysis, and leave that to future work, but suspect these kinds of results will continue to obtain were that undertaken. Remember that our results simply imply that the mix of commercial bank assets and the size of the central bank balance sheet are likely to matter for representative household welfare in a world of financial frictions.

\section{Conclusion}

Modern macroeconomics has been frequently criticised for its apparent inability to model financial questions. From the equity premium puzzle to the dominance of the representative agent, questions of risk and asymmetric information seem to have been side-stepped in our need to match aggregate behaviour with recourse to shocks rather than structure. The global financial crisis has provided a concrete incentive to develop models with financial frictions. And to some extent and with a limited departure from neoclassical microfoundations, it seems possible to introduce structures that allow financial developments to feedback substantively into agent decision rules. ${ }^{23}$ Indeed Kletzer (2012), after his careful summary of India's financial and monetary environment, calls for more analysis of the bank lending and asset price channel and accordingly this is to what we turn in this chapter.

In the model developed in this chapter, the set of interest rate premia that lead to market clearing in money and credit markets are closely linked to bank behaviour and to the evolution of asset prices. In advanced economies, these models were developed as a byproduct of the need to understand non-conventional monetary policy with either preferences for assets of different maturities or loan productions functions or bank capital to understand the evolution of financial frictions. ${ }^{24}$ In an emerging economy such as India's, which is moving towards greater levels of financialisation, the normative results in these models may help prevent the kind of enduring financial crisis being played out in the advanced world. Our results suggest that in the presence of substantive financial frictions, monetary policy makers have to pay attention to financial conditions as well as output and inflation when setting policy rates and also consider carefully the correct response to liquidity shortfalls and changes in velocity, when assessing the appropriate size of the central bank balance sheet and the mix of assets held by commercial banks. ${ }^{25}$

\footnotetext{
${ }^{23}$ We do though need more work to help those financially excluded to benefit from financial intermediation, see Chakravarty and. Pal, 2013.

${ }^{24}$ See Caglar et al. (2011) for a summary and papers by Harrison (2011) as well as Gertler and Karadi (2011) for the baseline papers. Also see Kim and Aum (2011) for results on the Korean economy.

${ }^{25}$ The RBI published some of its views in 2015 in a roadmap report to which our paper can be thought to be complementary.
} 


\section{References}

[1] Banerjee, S. and P. Basu. (2016). Effect of Quantitative Easing on the Indian Economy: a DSGE perspective, in this volume.

[2] Basel III, (2010). International Framework for liquidity risk measurement, standards and monitoring, http://www.bis.org/publ/bcbs188.htm.

[3] Bernanke, B. S., M. Gertler and S. Gilchrist. (1999). The Financial Accelerator in a Quantitative Business Cycle Framework. in: J. B. Taylor \& M. Woodford (ed.), Handbook of Macroeconomics, edition 1, volume 1, chapter 21, pages 1341-1393.

[4] Bernanke, B. S., M. Gertler and S. Gilchrist. (1999). The Financial Accelerator in a Quantitative Business Cycle Framework. in: J. B. Taylor \& M. Woodford (ed.), Handbook of Macroeconomics, edition 1, volume 1, chapter 21, pages 1341-1393.

[5] Breedon, Francis, Chadha, J. S. and Waters, Alex. (2012). The financial market impact of UK quantitative easing. Oxford Review of Economic Policy, Volume 28, Number 4, pp. $702-728$.

[6] Caglar, E., Chadha, J. S., Meaning, J., Warren, J. and A. Waters. (2011). Central Bank Balance Sheet Policies: Three Views From the DSGE Literature. Interest Rates, Prices and Liquidity. Cambridge University Press. pp. 240-273.

[7] Calomiris, C. W., M. Larrain, M. Liberti, and J. Sturgess. (2015). How Collateral Laws Shape Lending and Sectoral Activity. Mimeo.

[8] Chadha, J. S. and L. Corrado. (2012). Macro-prudential policy on liquidity: What does a DSGE model tell us? Journal of Economics and Business, vol 64, Issue 1, pp37-62.

[9] Chadha, J. S., L. Corrado and S. Holly. (2013a). A Note on Money and the Conduct of Monetary Policy. Macroeconomic Dynamics, 18(08), pp 1854-1883.

[10] Chadha, J. S., Corrado L. and J. Meaning. (2012). Reserves, Liquidity and Money: An Assessment of Balance sheet Policies. in: Bank for International Settlements (ed.), Are central bank balance sheets in Asia too large?, volume 66, pages 294-347 Bank for International Settlements.

[11] Chadha, J. S., L. Corrado and Q. Sun. (2010). Money and liquidity effects: Separating demand from supply. Journal of Economic Dynamics and Control, vol. 34(9), pp 17321747. . 
[12] Chadha, J. S. and S. Holly. (2011). (Ed) Interest Rates, Prices and Liquidity, 2011, Cambridge University Press.

[13] Chadha, J. S., P. Turner and F. Zampolli. (2013b). The Ties that Bind: Monetary Policy and Government Debt Management, Oxford Review of Economic Policy.

[14] Chadha, J. S. and Warren, James. (2012). Accounting for the great recession in the UK: Real business cycles and financial frictions. The Manchester School Vol 81 No. S2 43-64.

[15] Chakraborty, S. and K. Otsu. (2013). Business cycle accounting of the BRIC economies. B.E. Journal of Macroeconomics, vol. 13(1), pages 1-33.

[16] Chakravarty. S. R. and R. Pal. (2013). Financial Inclusion in India: An Axiomatic Approach. Journal of Policy Modelling, 35, pp 813-837.

[17] Chari V. V., Kehoe P. J. and E. R. McGrattan. (2007). Business Cycle Accounting. Econometrica, Vol. 75, Issue 3, pp.781-836.

[18] Gabriel, V., P. Levine and B. Yang. (2016). An Estimated DSGE Open-Economy Model of the Indian Economy with Financial Frictions, in this volume.

[19] Gabriel, V., P. Levine, J. Pearlman and B. Yang. (2012). An Estimated DSGE Model of the Indian Economy. Chapter 29 in Ghate (2012).

[20] Gale, D. (1982). Money in Equilibrium, Cambridge University Press.

[21] Galí, J., (2008). Monetary Policy, Inflation and the Business Cycle: An Introduction to the New Keynesian Framework, Princeton University Press.

[22] Gertler, M. and P. Karadi. (2011). A model of unconventional monetary policy. Journal of Monetary Economics, vol. 58(1), pages 17-34.

[23] Ghate, C. (2012). The Oxford Handbook of the Indian Economy, Oxford: Oxford University Press.

[24] Goodfriend, M. and B. T. McCallum. (2007). Banking and interest rates in monetary policy analysis: A quantitative exploration. Journal of Monetary Economics, 54(5), pp1480-1507.

[25] Goyal, A. (2014). Policy Actions and Outcomes, History of Monetary Policy in India since Independence, Springer. 
[26] Hall, R. (2009). The' High Sensitivity of Economic Activity to Financial Frictions. NBER mimeo.

[27] Hammond, G., R. Kanbur and E. S. Prasad. (2009). Monetary Policy Challenges for Emerging Market Economies, Brookings Global Economy and Development Working Paper 36.

[28] Harrison, R. (2011). Asset Purchase Policies and portfolio effects: a DSGE analysis. Chapter in Chadha and Holly (2011).

[29] International Monetary Fund. (2015). Article IV Consultation.

[30] Kehoe, T. J. and E. C. Prescott, (2002). Great Depressions of the Twentieth Century, Review of Economic Dynamics, 5(1), pp1-18.

[31] Kim, H. and Aum, S. (2011). The Role of Money and Banking in Monetary Policy: Does It Matter Quantitatively for the Korean Economy?, Economic Analysis, Vol 21 No.1, pp.45-102.

[32] King, R. G. and M. W. Watson, (1998). The Solution of Singular Linear Difference Systems under Rational Expectations, International Economic Review, 39(4), Symposium on Forecasting and Empirical Methods in Macroeconomics and Finance, pp1015-1026.

[33] Khan, A. and J. Thomas. (2014). Revisiting the Tale of Two Interest Rates with Endogenous Asset Market Segmentation. in press Review of Economic Dynamics.

[34] Kletzer, K. (2014). Financial Frictions and Monetary Policy transmission in India, Chapter 22 in Ghate.

[35] Mohanty, M. S. and K. Rishabh. (2016). Financial intermediation and monetary policy transmission in EMEs: what has changed post-2008 crisis?, in this volume.

[36] Reserve Bank of India. (2014). Report of the Expert Committee to Revise and Strengthen the Monetary Policy Framework. 


\section{Appendix}

\section{A First Order Condition and Market Clearing Condi- tion}

\section{A.1 First Order Condition}

\section{A.1.1 Households and Banking sector}

$$
\begin{gathered}
c_{t}: \quad \frac{\phi}{c_{t}}-\lambda_{t}-\mu_{t}=0 \\
B_{t+1}: \quad \frac{\mu_{t}}{\lambda_{t}} \Omega_{t}-1+\beta E_{t}\left(\frac{\lambda_{t+1}}{\lambda_{t}} \frac{P_{t}}{P_{t+1}}\left(1+R_{t}^{B}\right)\right)=0 \\
K_{t+1}: \quad \frac{\mu_{t}}{\lambda_{t}} k A 3_{t} q_{t} \Omega_{t}-q_{t}+\beta E_{t}\left(\frac{\lambda_{t+1}}{\lambda_{t}} \frac{\xi_{t+1}}{\lambda_{t+1}} \eta\left(\frac{K_{t+1}}{A 1_{t+1} n_{t+1}}\right)^{(\eta-1)}+\frac{\lambda_{t+1}}{\lambda_{t}} q_{t+1}(1-\delta)\right)=0
\end{gathered}
$$

where $\frac{\mu_{t}}{\lambda_{t}}=\frac{\phi}{c_{t} \lambda_{t}}-1$ measures households' marginal utility relative to shadow value of funds. $\Omega_{t}=\frac{\partial y_{t}}{\partial b_{t+1}}=\frac{\alpha y_{t}}{b_{t+1}+A 3_{t} k q_{t} K_{t+1}}$ is marginal value of bonds as collateral.

$$
\begin{gathered}
I_{t}: \quad-\lambda_{t}+\lambda_{t} q_{t}\left(1-S\left(\frac{I_{t}}{I_{t-1}}\right)-S^{\prime}\left(\frac{I_{t}}{I_{t-1}}\right) \frac{I_{t}}{I_{t-1}}\right)+\beta \lambda_{t+1} q_{t+1} S^{\prime}\left(\frac{I_{t+1}}{I_{t}}\right)\left(\frac{I_{t+1}}{I_{t}}\right)^{2}-\mu_{t}=0 \\
n_{t}^{s}, m_{t}^{s}: \quad \frac{1-\phi}{1-n_{t}^{s}-m_{t}^{s}}=w_{t} \lambda_{t} \\
m_{t}: \quad w_{t}=\frac{\mu_{t}}{\lambda_{t}}(1-\alpha) \frac{y_{t}}{m_{t}}
\end{gathered}
$$

\section{A.1.2 Firms (Wholesale Good Producing Firm and Retailer)}

$$
\begin{gathered}
n_{t}: \quad w_{t}=\frac{\xi_{t}}{\lambda_{t}}(1-\eta) \frac{y_{t}}{n_{t}} \\
m c_{t}=\frac{\epsilon-1}{\epsilon} \frac{\xi_{t}}{\lambda_{t}} \\
P_{t}^{f}: \quad \sum_{s=0}^{\infty} \theta^{s} E_{t}\left[\Lambda_{t, s} Y_{t, t+s}\left(\frac{P_{t}^{f}}{P_{t-1}}-\mathrm{X}_{\psi} \mathrm{mc}_{\mathrm{t}} \pi_{\mathrm{t}-1, \mathrm{t}+\mathrm{s}}\right)\right]=0
\end{gathered}
$$


where $P_{t}^{f}$ is forward looking firms' optimal price (resetting price), $\Lambda_{t, s}=\beta^{s}\left(\frac{c_{t+s}}{c_{t}}\right)^{-1}\left(\frac{P_{t}}{P_{t+s}}\right)$ is the households' stochastic discount factor, $X_{\psi}=1 / m c$ is desired markup. $m c_{t}$ is real marginal cost, $\pi_{t-1, t+s}=\frac{P_{t+s}}{P_{t-1}}$.

Aggregate price level is given by

$$
P_{t}: \quad P_{t}=\theta P_{t-1}+(1-\theta) \bar{P}_{t}^{*}
$$

where $\bar{P}_{t}^{*}$ is an index of prices set in period $t$ based on the forward-looking and backwardlooking price setting behaviour such that

$$
\bar{P}_{t}^{*}=\omega P_{t}^{b}+(1-\omega) P_{t}^{f}
$$

where $P_{t}^{b}$ is the price set by the backward-looking rule of thumb $\left(P_{t}^{b}=\bar{P}_{t-1}^{*}+\pi_{t-1}\right), P_{t}^{f}$ is the price set by forwardlooking firms, and $\omega$ is the degree of backward-lookingness and $1-\omega$ is forward-lookingess.

Hybrid New Keynesian Philips Curve is given by

$$
\widehat{\pi}_{t}=\kappa \widehat{m c}_{t}+\gamma_{f} E_{t}\left(\widehat{\pi}_{t+1}\right)+\gamma_{b} \widehat{\pi}_{t-1}+a 5_{t}
$$

\section{A.2 Market Clearing}

Resource Constraint

$$
y_{t}=c_{t}+I_{t}
$$

Financial Market (Deposits)

$$
D_{t}^{s}=D_{t}^{d}=\frac{P_{t} y_{t}}{v_{t}}
$$

Balanced Government Budget

$$
T_{t}=g_{t}-\operatorname{tax}_{t}=\frac{B_{t+1}}{P_{t}\left(1+R_{t}^{B}\right)}-\frac{B_{t}}{P_{t}^{A}}-\frac{r_{t}}{P_{t}} R_{t}^{I B}
$$




\section{B Steady States}

For the productivity and monitoring shocks we assume a trend growth rate equal to $A 2_{t}=$ $A 1_{t}=(1+\varrho)^{t}$. In steady state $q=1, A 2=A 1=(1+\varrho), \lambda$ shrinks at rate $\varrho$ so $\frac{\lambda_{t+1}}{\lambda_{t}}=\frac{1}{1+\varrho}$. There is no inflation so $P=1$ while capital grows at rate $\varrho$ in steady state. We use the constant steady-state bonds to output $\left(\right.$ boy $\left.=\frac{\mathrm{B}}{\left(1+R^{B}\right) y}\right)$. That is, we assume that the fiscal authority's policy is set in order to stabilize boyt at an exogenous policy-determined value.

\section{B.1 The Core Steady States}

The following 10 equations give the steady-stae value for $y, c, I, K, m, n, w, \lambda, \mu, \Omega$.

$$
\begin{aligned}
& y=c+I \\
& 1=\frac{v F}{1-r r}\left(\text { boy }+\frac{k K}{y}\right)^{\alpha}\left(\frac{m}{y}\right)^{1-\alpha} \\
& \Omega=\frac{\alpha}{\left(b o y+\frac{k K}{y}\right)} \\
& \frac{1-\phi}{1-n-m}=w \lambda \\
& w=\frac{\mu}{\lambda} \frac{(1-\alpha) y}{m} \\
& w=\frac{\epsilon-1}{\epsilon}(1-\eta)\left(\frac{K}{n(1+\varrho)}\right)^{\eta} \\
& \frac{\mu}{\lambda} k \Omega-1+\beta\left[\frac{1-\delta}{1+\varrho}+\eta \frac{\epsilon-1}{\epsilon}\left(\frac{K}{n(1+\varrho)}\right)^{\eta-1}\right]=0 \\
& \frac{1}{m c}=\left(\frac{K}{y(1+\varrho)}\right)^{\eta}\left(\frac{n}{y}\right)^{(1-\eta)} \\
& I=\frac{\rho+\delta}{1+\varrho} K \\
& \frac{\mu}{\lambda}=\frac{\phi}{c \lambda}-1
\end{aligned}
$$

\section{B.2 Other variables}

$$
D=\frac{y}{v}
$$




$$
\begin{aligned}
& r=r r D=r r \frac{y}{v} \\
& L=(1-r r) D=(1-r r) \frac{y}{v} \\
& T=g-t a x=b-b\left(1+R^{B}\right)-r R^{I B} \\
& b=b o y \times y \\
& R^{T}-R^{B}=L S Y^{B}=\Omega \\
& L S Y^{K}=k \times L S Y^{K} \\
& E F P=\frac{v m w}{(1-\alpha)(1-r r) y}=\frac{\mu}{\lambda} \frac{v}{(1-r r)} \\
& C E F P=(1-\alpha) \times E F P=\frac{v m w}{(1-r r) y}=(1-\alpha) \frac{\mu}{\lambda} \frac{v}{(1-r r)} \\
& \tau=R^{L}-R^{I B}
\end{aligned}
$$

Accordingly spreads between interest rates can be written as follows:

$$
\begin{aligned}
R^{T} & =\frac{1+\varrho}{\beta}-1 \\
R & =R^{T}-E F P \\
R^{L} & =R^{I B}+C E F P \\
R^{B} & =R^{T}-L S Y^{B} \\
R^{D} & =R(1-r r)
\end{aligned}
$$




\section{Log-linearization}

Consumption

$$
c_{t}=-c\left(\lambda \lambda_{t}+\mu \mu_{t}\right)
$$

Supply of labour

$$
w_{t}=\frac{n}{1-n-m} n_{t}+\frac{m}{1-n-m} m_{t}-\lambda_{t}
$$

Demand for labour in the goods sector

$$
w_{t}=m c_{t}+y_{t}-n_{t}
$$

Demand for monitoring work

$$
w_{t}=\mu_{t}-\lambda_{t}+y_{t}-m_{t}
$$

Broad liquidity problem

$$
y_{t}=v_{t}+r r_{t}+(1-\alpha)\left(a 2_{t}+m_{t}\right)+\alpha\left(\frac{b}{b o y+k K} b_{t+1}+\frac{k K}{b o y+k K}\left(a 3_{t}+q_{t}+K_{t+1}\right)\right)
$$

where boy $=\frac{B}{P\left(1+R^{B}\right) y}$ and $b_{t+1}=\frac{B_{t+1}}{P_{t}\left(1+R_{t}^{B}\right)}=b o y_{t}+y_{t}$

Marginal value of bond as collateral

$$
\Omega_{t}=\frac{k K}{b o y+k K / y}\left(y_{t}-q_{t}-K_{t+1}-a 3_{t}\right)+\frac{b}{b o y+k K / y} b_{t+1}
$$

Asset price

$$
\begin{aligned}
\left(1-k \Omega \frac{\mu}{\lambda}\right) q_{t}=\frac{\beta}{1+\varrho} & \left(1-\delta+\eta m c\left(\frac{K}{n(1+\varrho)}\right)^{\eta-1}\right)\left(E_{t} \lambda_{t+1}-\lambda_{t}\right) \\
& +\frac{\beta}{1+\varrho}(1-\delta) E_{t} q_{t+1}+k \Omega \frac{\mu}{\lambda}\left(\mu_{t}-\lambda_{t}+\Omega_{t}+a 3_{t}\right) \\
& \quad+\frac{\beta}{1+\varrho} \eta m c\left(\frac{K}{n(1+\varrho)}\right)^{\eta-1} E_{t}\left(m c_{t+1}+(1-\eta)\left(n_{t+1}+a 1_{t+1}\right)\right)
\end{aligned}
$$

Deposit in advance constraint (DIA)

$$
P_{t}+y_{t}=D_{t}+v_{t}
$$

production function

$$
y_{t}=\eta K_{t}+(1-\eta)\left(a 1_{t}+n_{t}\right)
$$


Goods Market Clearing Condition

$$
y_{t}=\frac{c}{y} c_{t}+\frac{I}{y} I_{t}
$$

Law of Motion of Capital

$$
K_{t+1}=\frac{1-\delta}{1+\varrho} K_{t}+\frac{\varrho+\delta}{1+\varrho} I_{t}
$$

Investment

$$
q_{t}=(1+\varrho)^{2} s\left[\left(I_{t}-I_{t-1}\right)-\beta\left(E_{t}\left(I_{t+1}\right)-I_{t}\right)\right]+\frac{\mu}{\lambda} \mu_{t}
$$

Inflation

$$
\pi_{t}=p_{t}-p_{t-1}
$$

Philips curve

$$
\pi_{t}=\gamma_{b} \pi_{t-1}+\gamma_{f} E_{t}\left(\pi_{t+1}\right)+\kappa m c_{t}+a 5_{t}
$$

Government Budget Constraint

$$
T T_{t}=b\left(b_{t+1}-b_{t}-R^{B}\left(b_{t}+R_{t}^{B}\right)\right)-r R^{I B}\left(r_{t}+R_{t}^{I B}\right)
$$

Riskless Interest Rate (Benchmark Interest Rate)

$$
R_{t}^{T}=\lambda_{t}-E_{t}\left(\lambda_{t+1}\right)+E_{t}\left(\pi_{t+1}\right)
$$

Liquidity Service Yield $\left(L S Y_{t}\right)$

$$
R_{t}^{T}-R_{t}^{B}=\mu_{t}-\lambda_{t}+\Omega_{t}
$$

External Finance Premium $\left(E F P_{t}\right)$

$$
E F P_{t}=v_{t}+w_{t}+m_{t}-y_{t}+r r_{t}=\mu_{t}-\lambda_{t}+v_{t}+r r_{t}
$$

Interbank Interest Rate (Policy Rate)

$$
R_{t}^{I B}=R_{t}^{T}-E F P_{t}
$$

Loan Interest Rate

$$
R_{t}^{L}=R_{t}^{I B}+(C) E F P_{t}
$$


Bond Interest Rate

$$
R_{t}^{B}=R_{t}^{T}-L S Y_{t}^{B}
$$

Deposit Interest Rate

$$
R_{t}^{D}=R_{t}^{I B}-\frac{r r}{1-r r} r r_{t}
$$

Monetary Policy Rule (Taylor Rule)

$$
R_{t}=\rho R_{t-1}+(1-\rho)\left(\phi_{\pi} \pi_{t}+\phi_{y} m c_{t}+\phi_{f} f_{t}\right)+a 4_{t}
$$

OMO Policy Rule (Fiscal Policy Rule)

$$
\operatorname{boy}_{t}=a 6_{t}=\rho_{\text {boy }} b o y_{t-1}+\epsilon_{t}^{\text {boy }}
$$

Velocity

$$
v_{t}=a 7_{t}
$$

Liquidity Preference

$$
\tau_{t}=a 8_{t}
$$

Endogenous Reserves

$$
r_{t}=\frac{1}{r R^{T}}\left(R^{I B} R_{t}^{I B}-R^{L} R_{t}^{L}+\tau \tau_{t}\right)
$$

Loans

$$
L_{t}=D_{t}-\frac{1}{1-r r} r r_{t}
$$


Table 1: Market Interest Rates

\begin{tabular}{ll}
\hline Interest rate & Equation \\
\hline Benchmark Interest Rate & $R_{t}^{T}=\beta E_{t}\left(\frac{\lambda_{t} P_{t+1}}{\lambda_{t+1} P_{t}}\right)-1$ \\
External Finance Premium & $E F P_{t}=\frac{v_{t} m_{t} w_{t}}{(1-\alpha)\left(1-r r_{t}\right) y_{t}}=\frac{\mu_{t} v_{t}}{\lambda_{t}\left(1-r r_{t}\right)}$ \\
Liquidity Service Yield on bond & $L S Y_{t}^{B}=\frac{\mu \mu_{t} \Omega_{t}}{\lambda_{t}} \Omega_{t}$ \\
Liquidity Service Yield on capital & $L S Y_{t}^{K} \times A Y_{t} L S$ \\
Policy rate & $R_{t}=\rho R_{t-1}+(1-\rho)\left(\phi_{\pi} \pi_{t}+\phi_{y} y_{t}+\phi_{f} f_{t}\right)$ \\
Deposit rate & $R_{t}^{D}=\left(1-r r_{t}\right) R_{t}$ \\
Loan rate & $R_{t}^{L}=R_{t}+C E F P_{t}$ \\
Bond rate & $R_{t}^{B}=R_{t}^{T}-L S Y_{t}^{B}$ \\
\hline
\end{tabular}

Table 2: Parameter Calibration

\begin{tabular}{lll}
\hline Parameter & Description & Value \\
\hline$\beta$ & 0.98 & Discount factor \\
$\kappa$ & 0.24 & Philips curve slope \\
$\alpha$ & 0.7 & Collateral weight in loan production \\
$1-\alpha$ & 0.3 & Monitoring weight in loan production \\
$\phi$ & 0.4 & Consumption weight in utility \\
$\eta$ & 0.4 & Capital weight in firm's production \\
$\delta$ & 0.025 & Depreciation rate of capital \\
$s$ & 4 & Elasticity of investment adjustment cost \\
$\varrho$ & 0.0125 & Trend growth rate \\
$\epsilon$ & 6 & Elasticity of substitution of differentiated goods \\
$F$ & 3.9 & Efficiency in Loan production \\
$k$ & 0.2 & Inferiority of capital as collateral \\
$\rho$ & 0.8 & Interest rate smoothing in Taylor rule \\
$\phi_{\pi}$ & 1.5 & Response to inflation gap in Taylor rule \\
$\phi_{y}$ & 0.5 & Response to output gap in Taylor rule \\
$\phi_{f}$ & $0-1.5$ & Response to financial condition in Taylor rule \\
\hline
\end{tabular}


Table 3: Steady States

\begin{tabular}{|c|c|c|}
\hline Variable & Value & Description \\
\hline$y$ & 0.9505 & Output \\
\hline$c$ & 0.6948 & Consumption \\
\hline$I$ & 0.2557 & Investment \\
\hline$K$ & 6.9035 & Capital \\
\hline$m$ & 0.0045 & Employment in Banking sector \\
\hline$n$ & 0.3463 & Employment in Goods producing sector \\
\hline$w$ & 1.6469 & Real Wage \\
\hline$\lambda$ & 0.5611 & Shadow value of Consumption \\
\hline$\mu$ & 0.0146 & Shadow value of DIA constraint \\
\hline$\Omega$ & 0.3178 & Marginal value of consumption \\
\hline$v$ & 0.588 & Velocity \\
\hline$c / y$ & 0.73 & Consumption to GDP \\
\hline$I / y$ & 0.27 & Investment to GDP \\
\hline$K / y$ & 7.26 & Capital to GDP \\
\hline $\operatorname{boy}(=b / y)$ & 0.75 & Bond to GDP \\
\hline $\mathrm{rr}$ & 0.2 & Reserve to Deposit Ratio \\
\hline$L$ & 1.2932 & Loans \\
\hline$L S Y^{B}$ & $3.3 \%$ & Liquidity Service Yield (Bonds) \\
\hline$L S Y^{K}$ & $0.7 \%$ & Liquidity service yield (Capital) \\
\hline EFP & $7.6 \%$ & Uncollateralised External Finance Premium \\
\hline$C E F P$ & $2.3 \%$ & Collateralised External Finance Premium \\
\hline$R^{T}$ & $13.1 \%$ & Risk Free Rate \\
\hline$R^{I B}$ & $5.6 \%$ & Interbank Rate \\
\hline$R^{L}$ & $7.9 \%$ & Loan Rate \\
\hline$R^{B}$ & $9.8 \%$ & Bond Rate \\
\hline
\end{tabular}

Note: Market interest rates and Service yields are annualised.

Table 4: Properties of Exogenous Shocks

\begin{tabular}{lll}
\hline Shock & Persistence & Standard Deviation \\
\hline Productivity & 0.95 & $1.0 \%$ \\
Monitoring & 0.5 & $1.0 \%$ \\
Collateral & 0.5 & $1.0 \%$ \\
Monetary Policy & 0 & $1.0 \%$ \\
Mark Up & 0.7 & $1.0 \%$ \\
Bond Holdings & 0.7 & $1.0 \%$ \\
Velocity & 0.5 & $1.0 \%$ \\
Liquidity & 0.33 & $1.0 \%$ \\
\hline
\end{tabular}


Table 5: Moments of Simulated Series from the Model

\begin{tabular}{lllll}
\hline & \multicolumn{2}{l}{ Fixed Reserve Ratio } & \multicolumn{2}{l}{ Endogenous Reserve Ratio } \\
\hline Variables & $S . D(\%)$ & Corr $(i, y)$ & S.D(\%) & Corr $(i, y)$ \\
\hline Output & 1.01 & 1.00 & 1.20 & 1.00 \\
Consumption & 1.01 & 0.95 & 0.92 & 0.89 \\
Investment & 1.44 & 0.79 & 2.50 & 0.89 \\
Inflation & 3.07 & 0.24 & 1.15 & -0.03 \\
Employment in Goods Sector & 1.55 & 0.81 & 1.59 & 0.83 \\
Employment in Monitoring & 4.96 & -0.73 & 4.74 & -0.76 \\
Real Wages & 3.14 & 0.95 & 2.92 & 0.92 \\
Asset Price & 2.46 & 0.91 & 2.27 & 0.80 \\
External Finance Premium & 2.46 & -0.43 & 2.12 & -0.49 \\
Liquidity Service Yield & 4.37 & -0.64 & 3.95 & -0.68 \\
Policy Interest Rate & 2.15 & -0.27 & 1.32 & 0.07 \\
Loan Interest Rate & 2.15 & -0.76 & 1.52 & -0.62 \\
Real Deposits & 0.94 & 0.43 & 1.20 & 0.62 \\
Reserve Ratio & 0.00 & 0.00 & 1.07 & 0.61 \\
\hline
\end{tabular}

Note: S.D. and Corr denote the asymptotic standard deviation, and contemporaneously cross-correlation between the relevant variable and output from the filtered second moments obtained from the model.

Table 6: Approximated Welfare Loss

\begin{tabular}{llllll}
\hline & & \multicolumn{2}{c}{ Benchmark Scenario } & \multicolumn{2}{c}{ Banking Dominant Scenario } \\
\hline & Parameter on EFP & Fixed & Endogenous & Fixed & Endogenous \\
\hline Standard Rule & $\phi_{f}=0$ & 1.8290 & 0.1616 & 2.6589 & 0.2593 \\
Augmented Rule & $\phi_{f}=0.25$ & 1.7235 & 0.1643 & 2.2224 & 0.2510 \\
& $\phi_{f}=0.5$ & 1.6251 & 0.1674 & 1.9156 & 0.2430 \\
& $\phi_{f}=0.75$ & 1.5337 & 0.1708 & 1.7640 & 0.2361 \\
& $\phi_{f}=1$ & 1.4577 & 0.1744 & 1.7995 & 0.2309 \\
\hline
\end{tabular}

Note: Banking dominant scenario denotes the case where the standard deviation of banking shocks is 5 times higher than in the benchmark calibration 
Figure 1: The Simple NK Framework

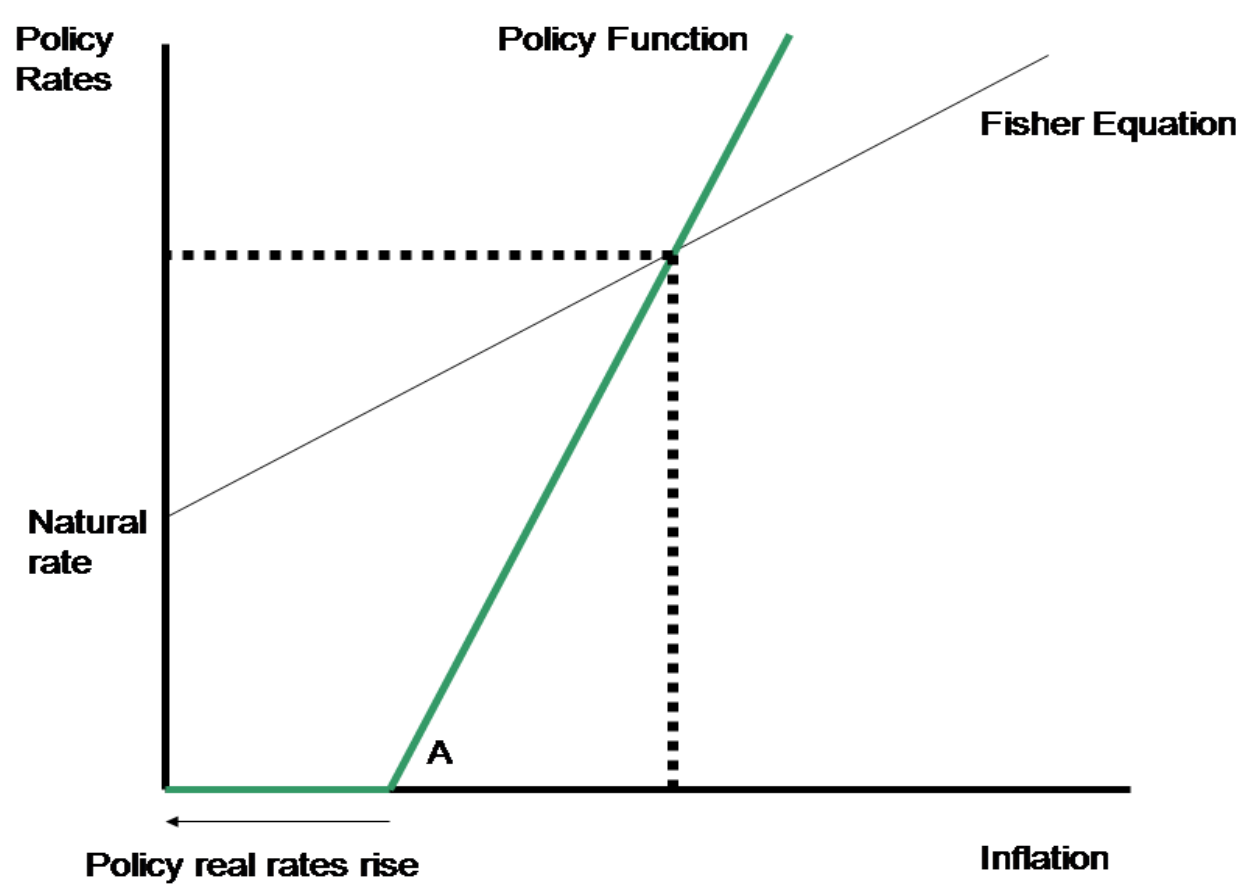

Figure 2: Money, EFP and Demand

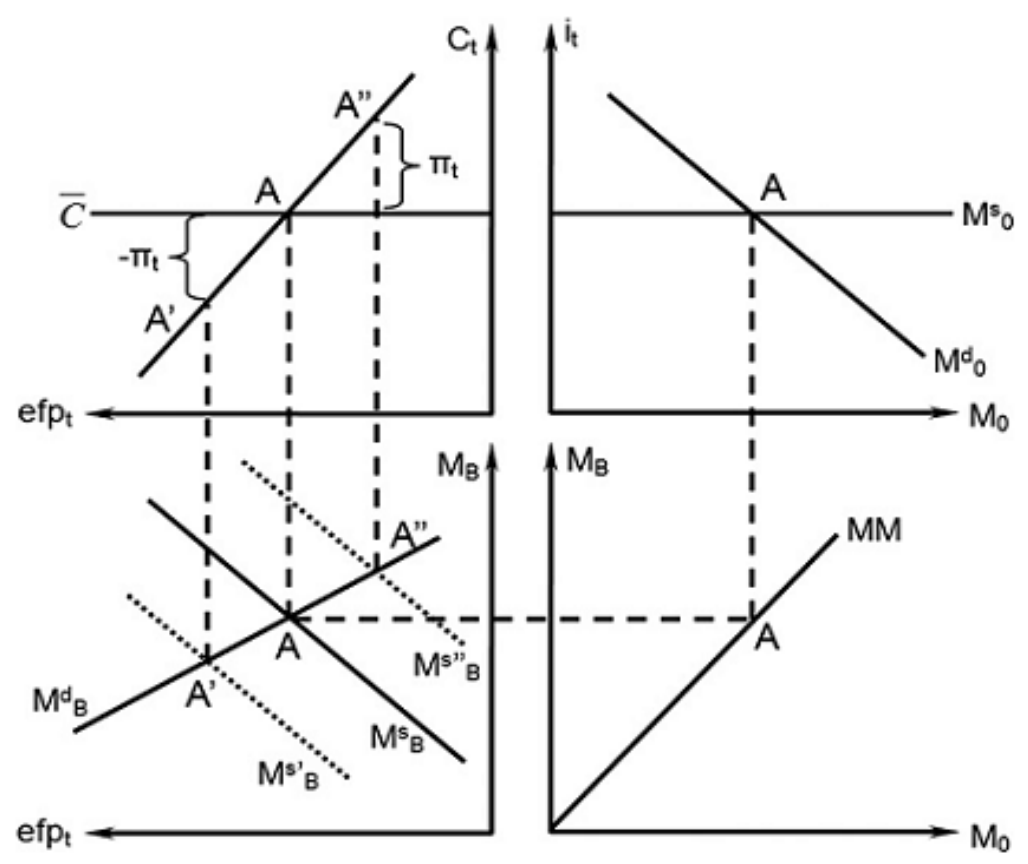


Figure 3: The Flow of Funds

\begin{tabular}{|c|c|c|c|}
\hline \multicolumn{2}{|c|}{ Private Sector } & \multicolumn{2}{|c|}{ Government } \\
\hline$\underline{\text { Assets }}$ & $\underline{\text { Liabilities }}$ & Assets & $\underline{\text { Liabilities }}$ \\
\hline Deposits $D$ & Loans $L$ & $\operatorname{Tax} T$ & Bonds $B$ \\
\hline Bonds $\quad \gamma B$ & $\operatorname{Tax} T$ & & \\
\hline Capital $K$ & Capital $K$ & & \\
\hline \multicolumn{4}{|c|}{$\begin{array}{l}\text { Posted for loan } \\
\text { production }\end{array}$} \\
\hline \multicolumn{2}{|c|}{ Commercial Banks } & \multicolumn{2}{|c|}{ Central Bank } \\
\hline$\underline{\text { Assets }}$ & $\underline{\text { Liabilities }}$ & $\underline{\text { Assets }}$ & Liabilities \\
\hline Reserves $r$ & Deposits $D$ & Bonds $(1-\gamma) B$ & Reserves $r$ \\
\hline Loans $L$ & & & \\
\hline
\end{tabular}

Figure 4: Commercial Bank's Demand for Reserves

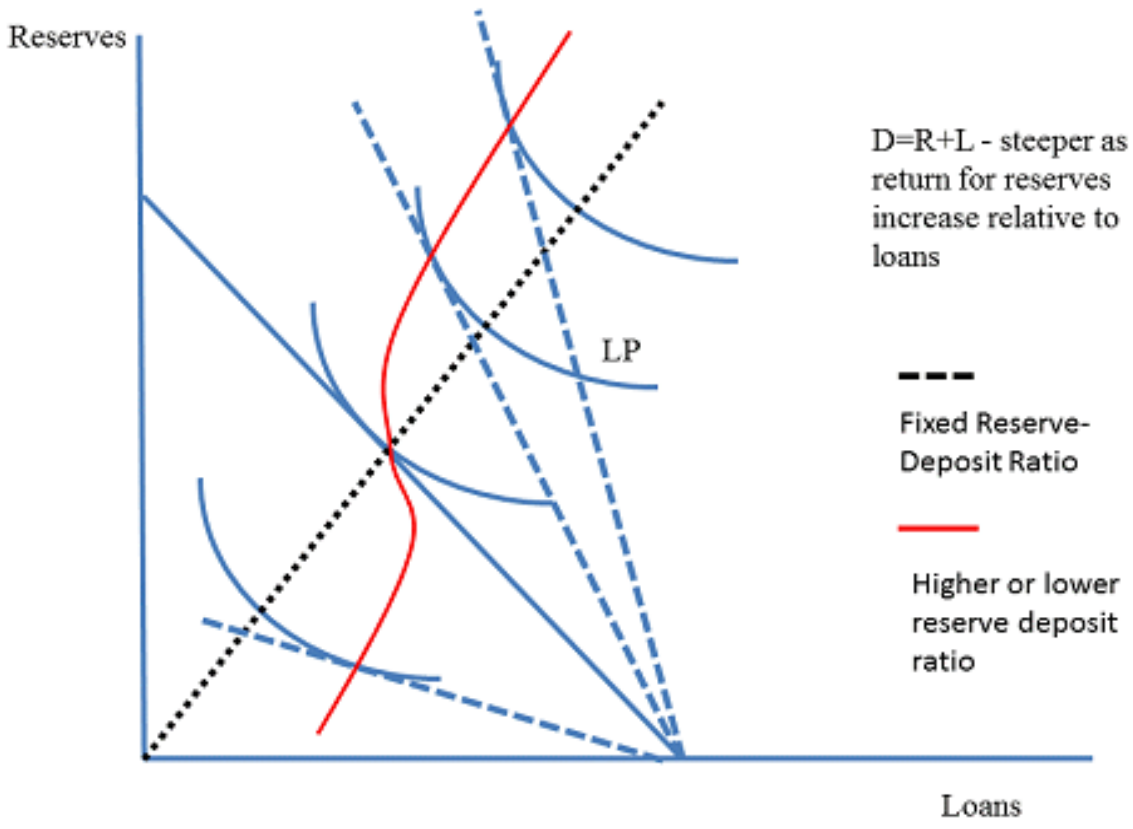


Figure 5: Simulation of Series of HP filtered the Model Under the Benchmark Scenario
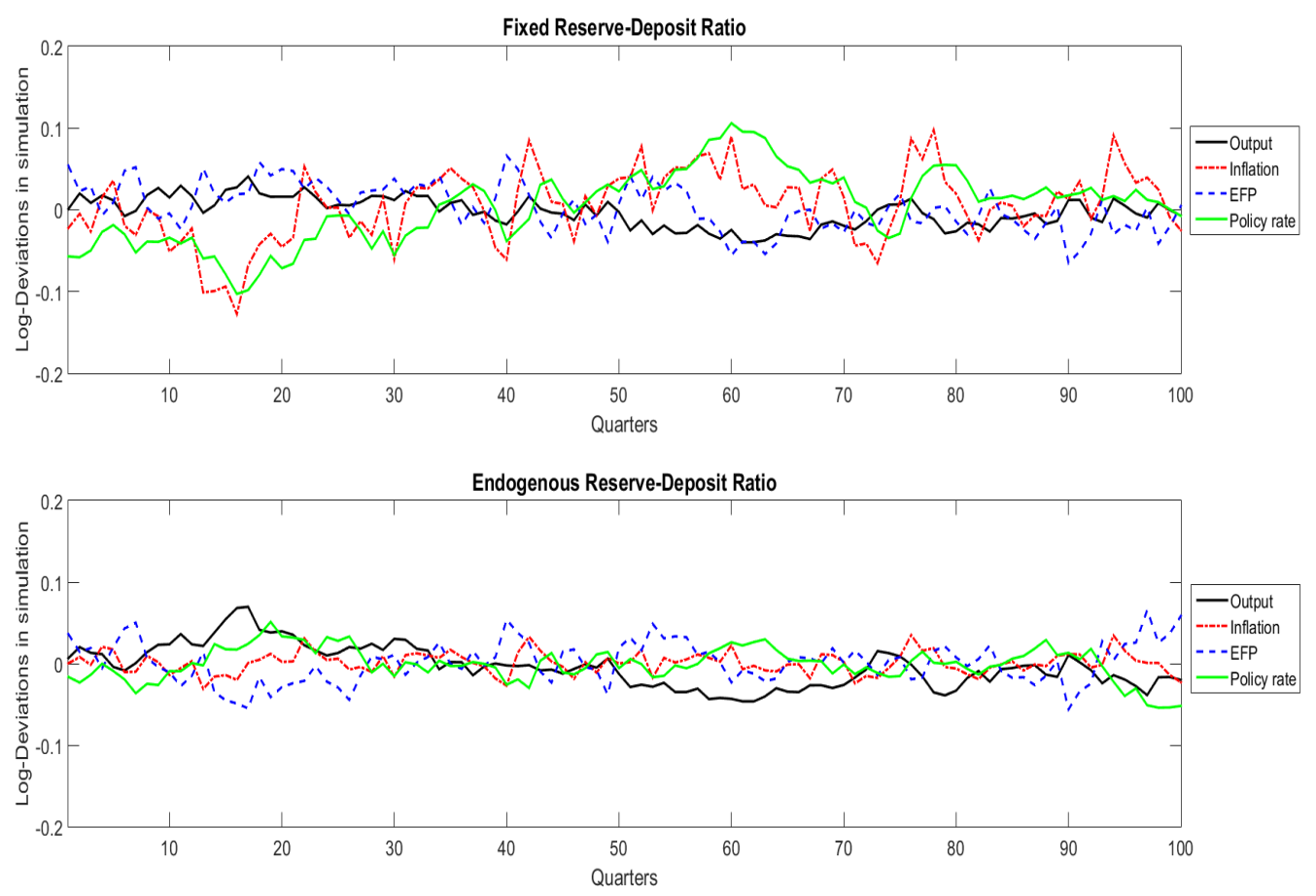

Note: The series show the middle segment of a simulation of 5,000 data points from a benchmark calibration. The simulated data are HP filtered $(\lambda=1600)$. 
Figure 6: Simulation of Series of HP filtered the Model under the Banking Dominant Scenario
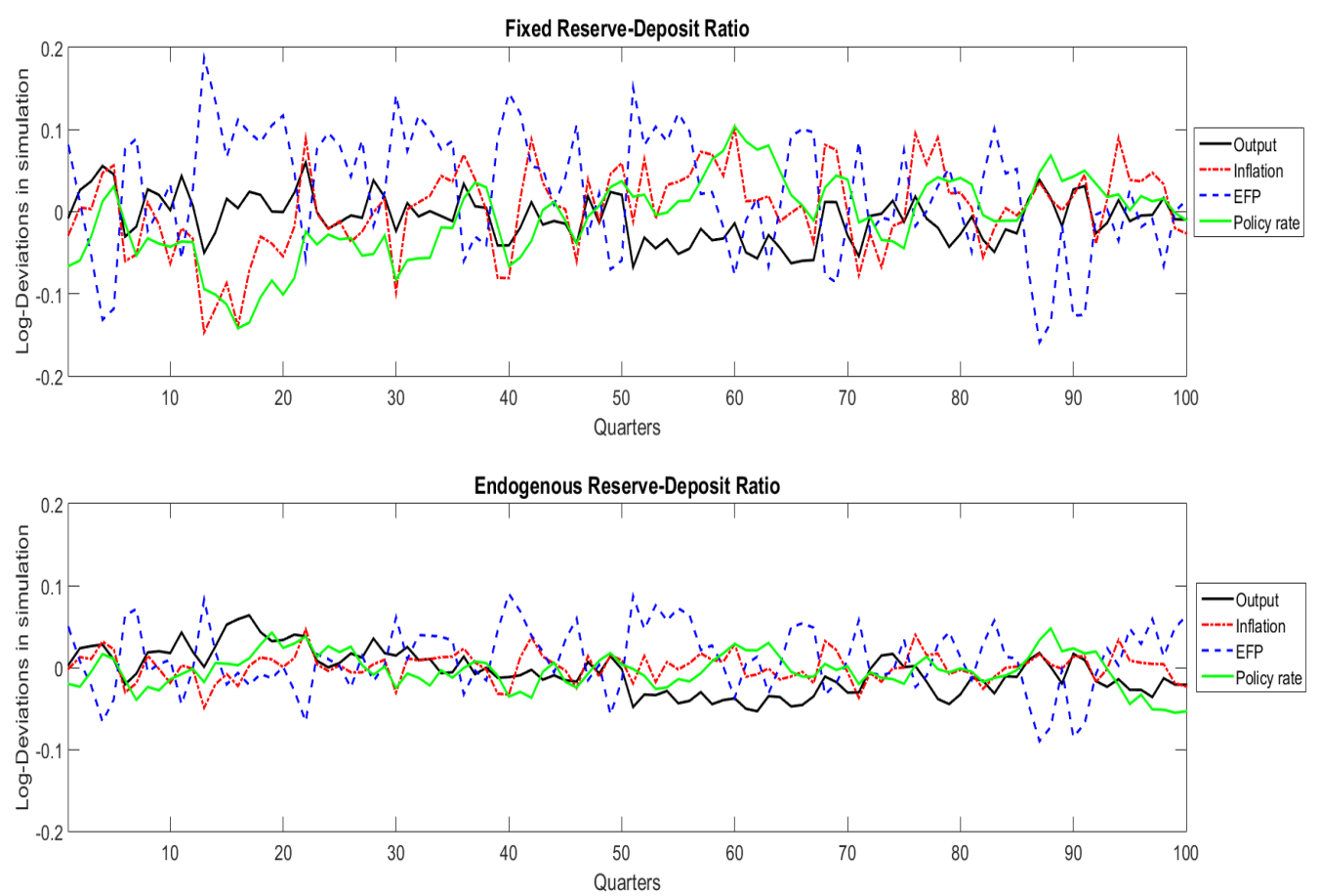

Note: The series show the middle segment of a simulation of 5,000 data points from a calibration where the standard deviation of banking shocks is 5 times higher than in the benchmark calibration. The simulated data are HP filtered $(\lambda=1600)$. 
Figure 7: Impulse response to a positive productivity shock $(+1 \%)$
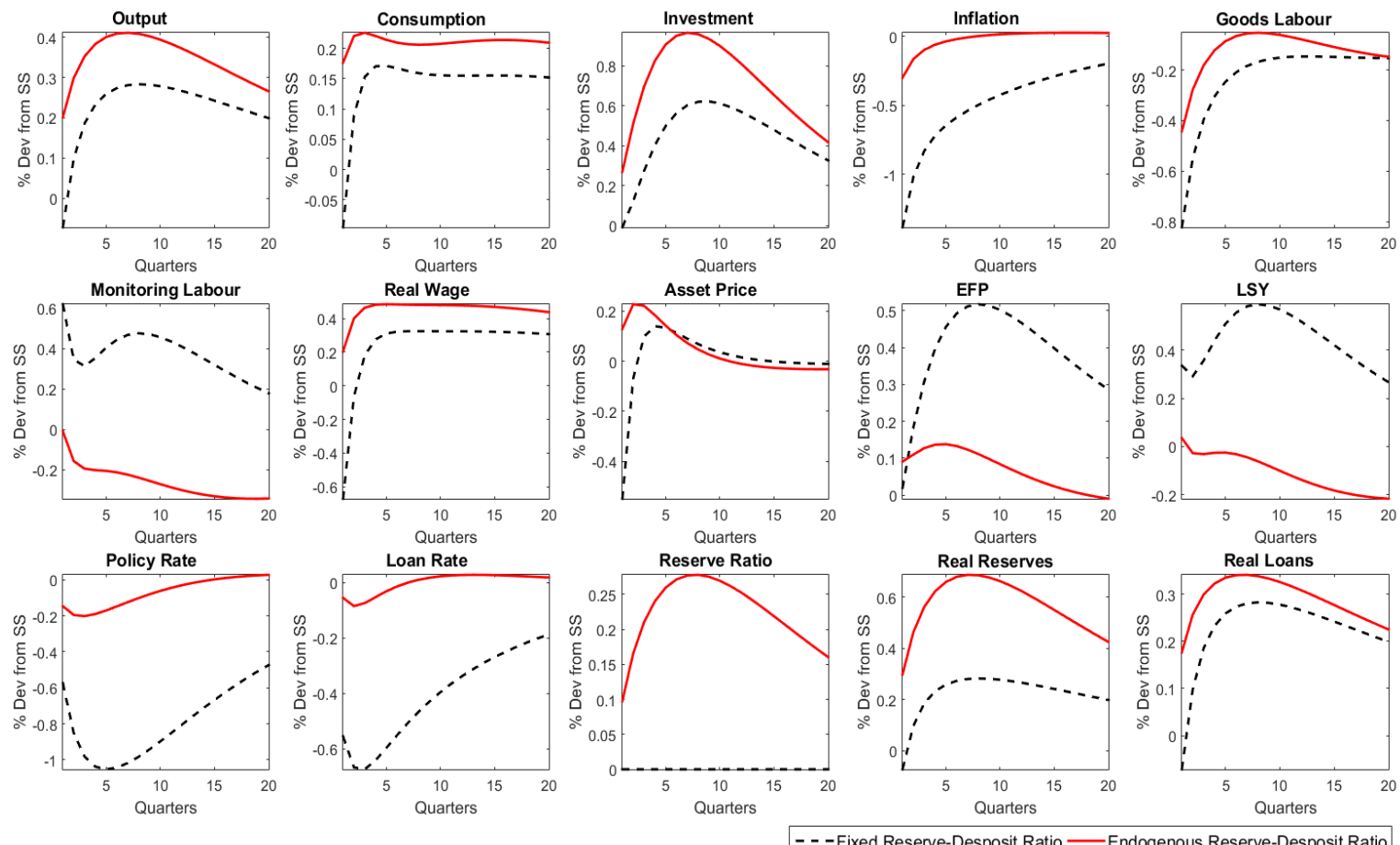

Figure 8: Impulse response to a positive banking productivity shock $(+1 \%)$
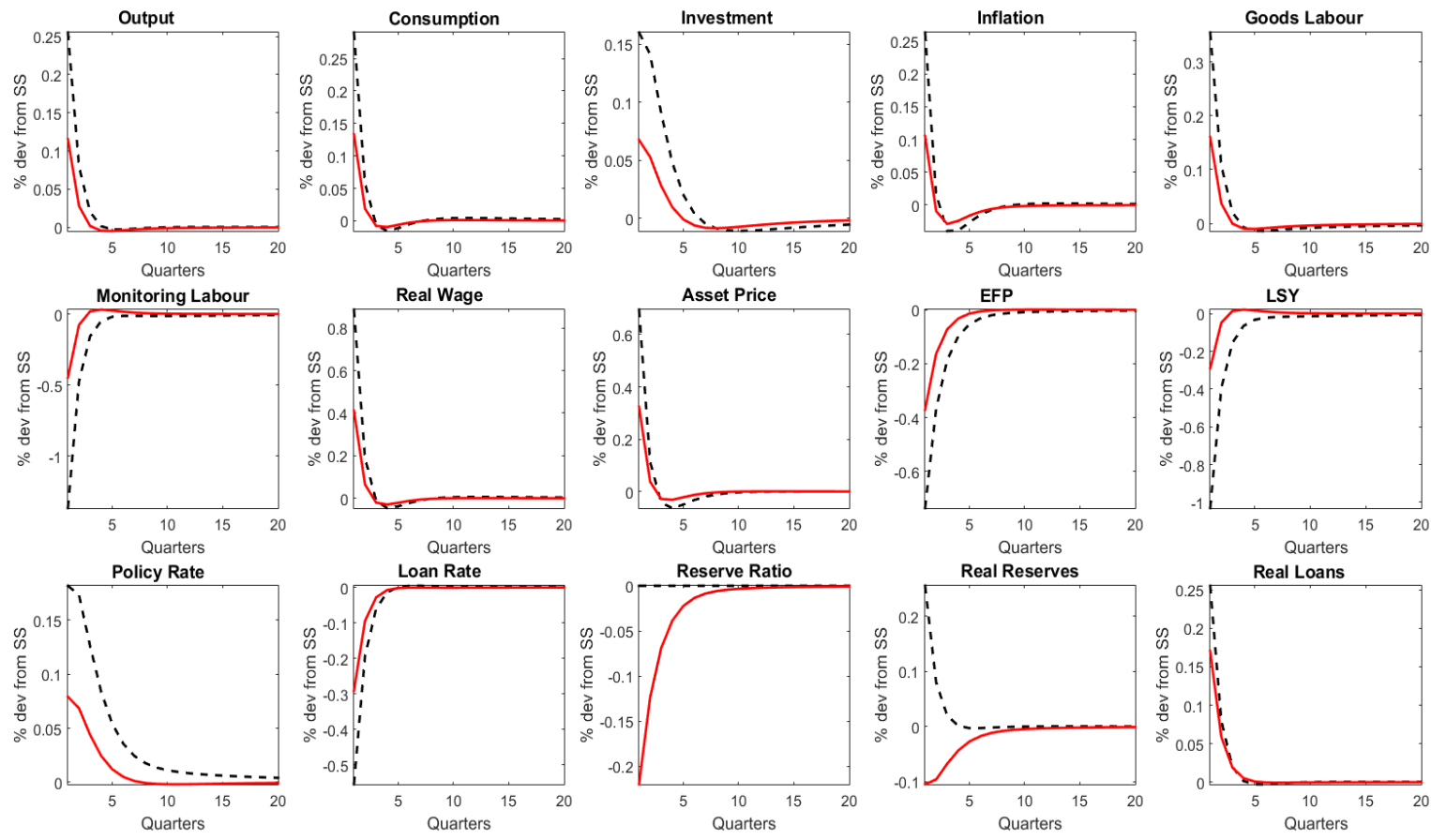

- - -Fixed Reserve-Desposit Ratio — Endogenous Reserve-Desposit Ratio 
Figure 9: Impulse response to a positive collateral shock $(+1 \%)$
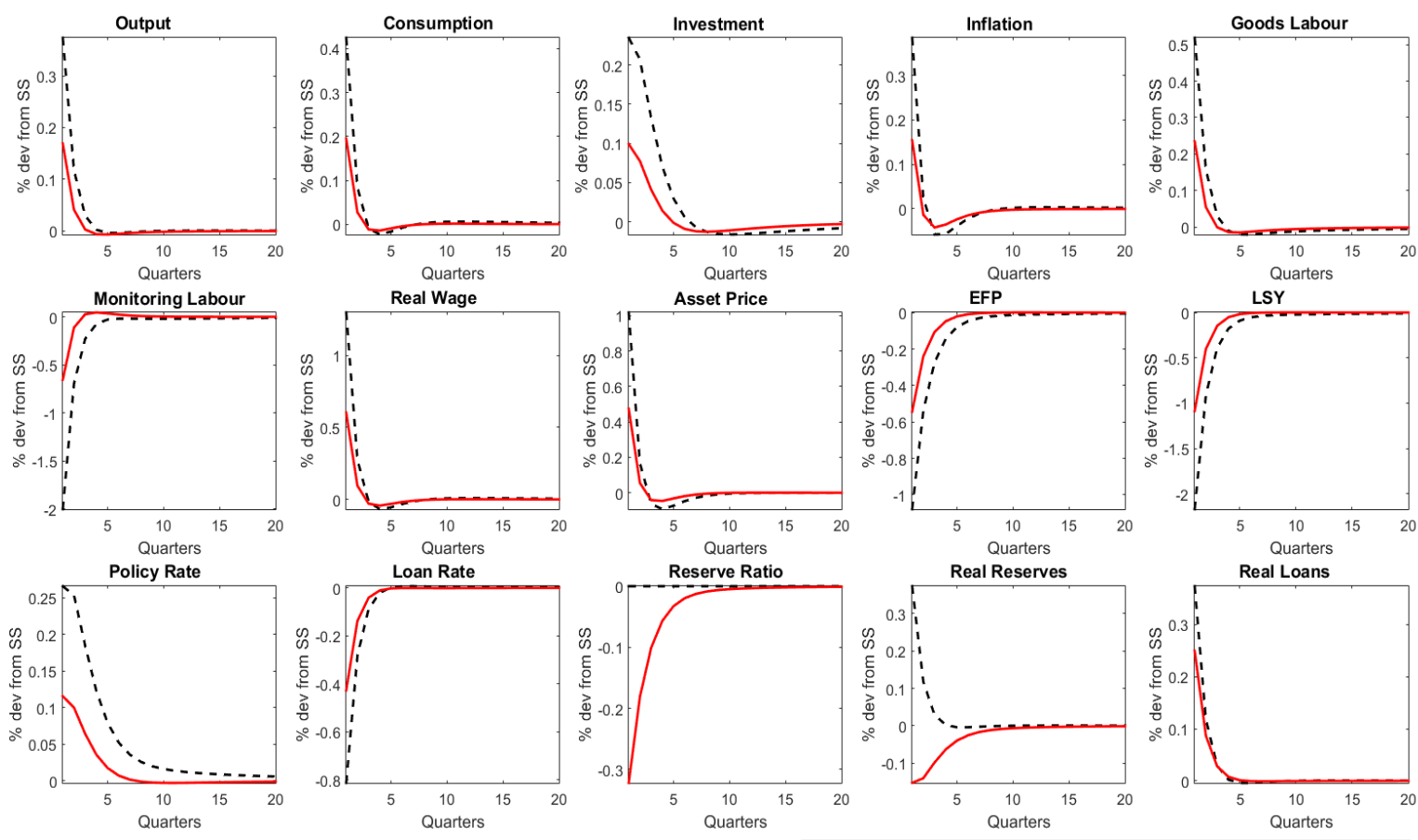

- - -Fixed Reserve-Desposit Ratio ——Endogenous Reserve-Desposit Ratio

Figure 10: Impulse response to a positive policy rate shock $(+1 \%)$
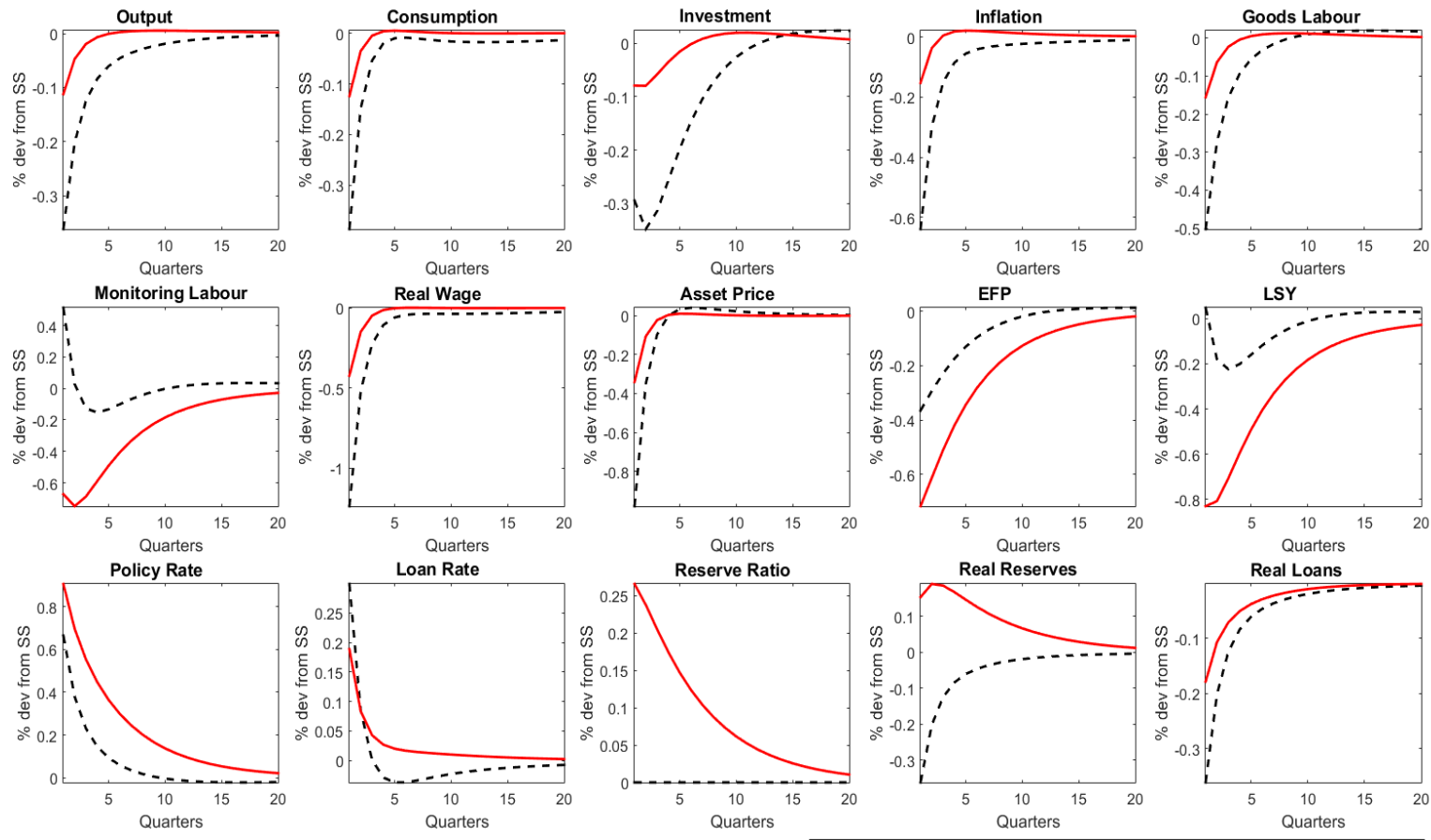

- - -Fixed Reserve-Desposit Ratio — Endogenous Reserve-Desposit Ratio 